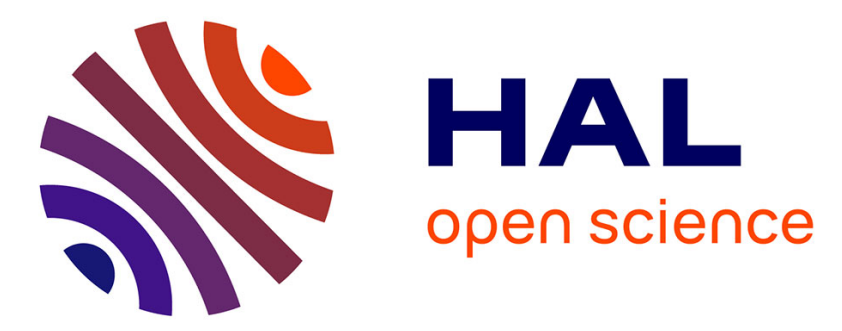

\title{
Temporal Variability of Benthic Communities in an Alaskan Glacial Fjord, 1971-2007
}

\author{
Arny L. Blanchard, Howard M. Feder, Max K. Hoberg
}

\section{To cite this version:}

Arny L. Blanchard, Howard M. Feder, Max K. Hoberg. Temporal Variability of Benthic Communities in an Alaskan Glacial Fjord, 1971-2007. Marine Environmental Research, 2010, 69 (2), pp.95. 10.1016/j.marenvres.2009.08.005 . hal-00563097

\section{HAL Id: hal-00563097 https://hal.science/hal-00563097}

Submitted on 4 Feb 2011

HAL is a multi-disciplinary open access archive for the deposit and dissemination of scientific research documents, whether they are published or not. The documents may come from teaching and research institutions in France or abroad, or from public or private research centers.
L'archive ouverte pluridisciplinaire HAL, est destinée au dépôt et à la diffusion de documents scientifiques de niveau recherche, publiés ou non, émanant des établissements d'enseignement et de recherche français ou étrangers, des laboratoires publics ou privés. 


\section{Accepted Manuscript}

Temporal Variability of Benthic Communities in an Alaskan Glacial Fjord, 1971-2007

Arny L. Blanchard, Howard M. Feder, Max K. Hoberg

PII:

S0141-1136(09)00109-3

DOI:

10.1016/j.marenvres.2009.08.005

Reference:

MERE 3366

To appear in:

Marine Environmental Research

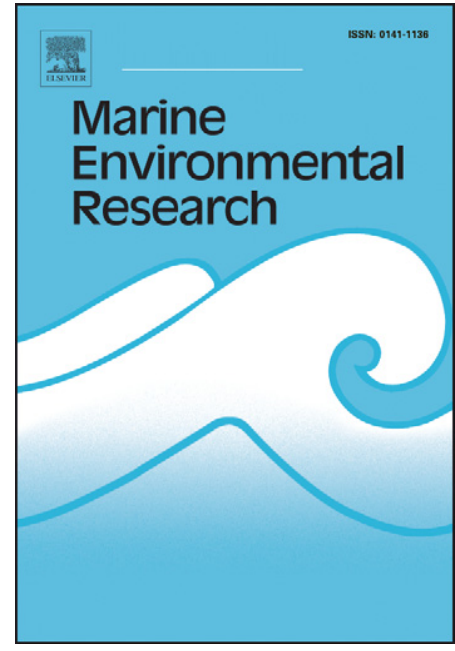

Received Date: $\quad 3$ March 2009

Revised Date: $\quad 20$ August 2009

Accepted Date: $\quad 24$ August 2009

Please cite this article as: Blanchard, A.L., Feder, H.M., Hoberg, M.K., Temporal Variability of Benthic Communities in an Alaskan Glacial Fjord, 1971-2007, Marine Environmental Research (2009), doi: 10.1016/ j.marenvres.2009.08.005

This is a PDF file of an unedited manuscript that has been accepted for publication. As a service to our customers we are providing this early version of the manuscript. The manuscript will undergo copyediting, typesetting, and review of the resulting proof before it is published in its final form. Please note that during the production process errors may be discovered which could affect the content, and all legal disclaimers that apply to the journal pertain. 
8 ABSTRACT: Temporal trends of deep subtidal macrofauna in Port Valdez, Alaska, were
Temporal Variability of Benthic Communities in an Alaskan Glacial Fjord, 1971-2007
Arny L. Blanchard ${ }^{1}$, Howard M. Feder, and Max K. Hoberg P.O. Box 757220, Institute of Marine Science, University of Alaska Fairbanks, Fairbanks, Alaska USA, 99775-7220. assessed with respect to multiple environmental stressors. Effects from a magnitude 9.2 earthquake in Prince William Sound, Alaska, 1964, were reflected in recolonization of

1 the basin of the fjord, increased abundance and number of taxa over time, and moderately

2 increased variability in abundance through 1990, stabilizing 26 years after the

3 earthquake. Long-term climatic variability and local physical processes were important

14 sources of spatial and temporal variability. Correlative evidence suggests that indirect

5 effects of juvenile salmon from a shoreline salmon hatchery and deposition of adult 16 salmon carcasses moderately enhanced deep basin benthic communities. Effects on the

17 deep benthos from a marine oil terminal were negligible. Overall, faunal trends deviated

18 from the stability expected for benthic communities in other fjords. Physical

9 characteristics of the fjord were important in mediating the effects of stressors and in 0 delaying the readjustment process.

2 Keywords: Benthos; Earthquake; Port Valdez; Prince William Sound; Marine Oil

3 Terminal; Multiple Stressors; Disturbance; Long-Term Monitoring; Climate Change.

5 1. Introduction

6 The coastal fringe is a multiple-use region where frequent environmental

27 perturbations from natural and anthropogenic stressors can have large, long-lasting

28 effects (Lindegarth and Hoskin, 2001). Human activities can result in temporally

2 persistent changes and stress in coastal environments through disturbance as varied as

30 nonindigenous species introductions, alteration of drainage patterns by industrial and

1. Corresponding Author. Email arnyb@ims.uaf.edu. 
1 urban development, dredging, and waste disposal (Nichols, 1985; Nichols and

2 Thompson, 1985; Pearson and Barnett, 1987; Burd et al., 2000; Perus and Bonsdorff,

3 2004). Changes in nearshore environments often reflect increasing stress from urban

4 growth and development with the direction of change towards greater habitat loss and

5 long-term disturbance to marine communities (Schiff et al., 2000). In view of large-scale

6 changes in the marine environment resulting from climate change, human activities, and

7 landscape-scale changes, understanding how communities vary in response to stressors

8 becomes critical.

$9 \quad$ Assessment of disturbance in marine communities is complicated by multiple

10 stressors acting and interacting over varying spatial and temporal scales (Blanchard and

11 Feder, 2003; Hewitt et al., 2005). Preferably, undisturbed community characteristics and

12 information on natural sources and directions of change should be available prior to a

13 disturbance (Nichols, 1985). This is difficult since marine communities are continually

14 adjusting to long-term change from varied sources of stress such as nonindigenous

15 species introductions, global climatic change, global spread of contaminants,

16 urbanization, and increasing resource use (Steneck and Carlton, 2001; Dojiri et al., 2003;

17 Hewitt et al., 2005). Small, localized disturbances from human activities can often be

18 readily identified (Blanchard et al., 2002, 2003; Blanchard and Feder, 2003) whereas

19 determination of community readjustment from perturbations large enough to impact

20 whole marine ecosystems (Josefson and Rosenberg, 1988; Austen et al., 1991; Lay et al.,

21 2005) is more difficult. Although the effects of stressors cannot always be predicted,

22 long-term studies of disturbed systems provide a means to gain insights into the

23 responses to stress and temporal variability of marine communities and long-term trends

24 (Hawkins et al., 2002; Whomersley et al., 2007).

25 Physical and ecological characteristics of glacial fjords result in strong

26 environmental sensitivity to natural and anthropogenic stressors. Deep basins in glacial

27 fjords are sheltered environments with restricted exchange with oceanic water and are

28 highly stratified with only seasonal mixing of deep water (Muench and Nebert, 1973;

29 Jewett et al., 1996; Burd et al., 2000; Renaud et al., 2007). The restricted circulation and

30 stratification in silled-fjords limits larval dispersion, nutrient exchange, and deep water

31 renewal as well (Jewett et al., 1996; Josefson and Rosenberg, 1988; Burd et al., 2000; 
1 Molinet et al., 2006; Renaud et al., 2007). The fine glacial sediments deposited in glacial

2 fjords form unstable slopes, bury juvenile and adult macrofauna, and dilute particulate

3 organic carbon (POC) (Görlich et al., 1987; Feder and Jewett, 1988; Holte et al., 1996;

4 Wlodarska-Kowalczuk and Pearson, 2004; Renaud et al., 2007). Fluxes of organic

5 carbon to deep basins of fjords may be on the order of 1-3 $\mathrm{g} \mathrm{C} \mathrm{m}^{-2} \mathrm{year}^{-1}$, as in the

6 Balsfjord in Norway and Port Valdez, Alaska, resulting in carbon-poor benthic systems

7 with low infaunal abundance and biomass (Feder and Jewett, 1988; Wlodarska-

8 Kowalczuk et al., 1998; Oug, 2000; Renaud et al., 2007). Spatial gradients in fauna and

9 community structure may show little change on decadal scales but the sensitivity of fauna

10 to long-term climatic change is unknown (Renaud et al., 2007). As a result of their

11 physical and ecological characteristics, glacial fjords can be very sensitive to

12 anthropogenic disturbance (Josefson and Rosenberg, 1988; Holte et al., 1996; Burd et al.,

13 2000; Blanchard and Feder, 2003; Renaud et al., 2007). The restricted circulation and

14 thus, isolation of deep basins of glacial fjords contributes to their importance as sites for

15 monitoring long-term change (Josefson and Rosenberg, 1988; Holte et al., 1996; Renaud

16 et al., 2007).

17 A 35-year investigation of the deep-subtidal macrofauna in Port Valdez, Alaska,

18 provides the opportunity to examine the temporal variability of benthic organisms in a

19 glacial fjord during a period with large environmental changes. Environmental

20 perturbations in the study area include a major earthquake in 1964 and increasing

21 anthropogenic stresses (1971-2005) (Feder and Jewett, 1988; McRoy, 1988; Wiegers et

22 al., 1998). Regional climatic variations have been identified as key factors for ecological

23 processes in the Gulf of Alaska and Prince William Sound (PWS) ecosystems (Mundy

24 and Spies, 2005) contributing to temporal variability of infaunal communities in Port

25 Valdez and PWS. Additionally, limited responses of fauna to short-term increases in

26 sediment hydrocarbons have been observed in shallow sediments adjacent to the marine

27 oil terminal in Port Valdez (Blanchard et al., 2002). Objectives of this study were to

28 examine the macrofaunal community in the deep basin of the fjord from 1971 to 2007 to

29 determine if temporal variability represented biologically significant deviations from the

30 stability expected of fjord-basin communities and to gain insights into the influences of

31 climatic variability, natural gradients, and stressors on variability in community structure. 
2 2. Study area

3 Sampling occurred in Port Valdez, a glacial outwash fjord in the northeastern 4 corner of PWS (Hood et al., 1973; Colonell, 1980b; Shaw and Hameedi, 1988) (Figure

5 1). Port Valdez has two sills (at 120 and $200 \mathrm{~m}$ depth) and a relatively flat bottom in the

6 deep basin varying between 230-250 m depth. In summer, positive estuarine circulation

7 occurs within surface waters to about $15 \mathrm{~m}$ (Muench and Nebert, 1973; Sharma and

8 Burbank, 1973; Colonell, 1980a). The counterclockwise movement of water is slow ( $<5$

$9 \mathrm{~cm} \mathrm{sec}^{-1}$ ) with a residence time estimated as 40 days. Deep-water layers below sills ( $>$

$10120 \mathrm{~m}$ ) have little exchange with upper water layers in summer but are well mixed in

11 winter (Colonell, 1980a). The sediment is dominated by silt and clay fractions carried to

12 the fjord in glacial melt water from the surrounding mountains. Seasonal variations in

13 sediment flux are large ranging from less than $5 \mathrm{mg} \mathrm{cm}^{-2}$ day ${ }^{-1}$ in winter up to $48 \mathrm{mg} \mathrm{cm}^{-2}$

$14 \mathrm{day}^{-1}$ in summer with highest sediment fluxes obseryed in the eastern end of the fjord

15 (Feder and Matheke, 1980; Fig. 2). Annual sedimentation rate at the eastern end of the

16 fjord was estimated to be $13.5 \mathrm{~cm} \mathrm{yr}^{-1}$ but $<1 \mathrm{~cm} \mathrm{yr}^{-1}$ at the western end (Naidu and

17 Klein, 1988). Macrofaunal communities in the fjord's basin demonstrated relatively low

18 numbers overall and moderate gradients in community structure associated with high

19 sediment loads from glacial rivers (Feder and Matheke, 1980; Feder and Jewett, 1988).

20 An east to west division of faunal communities was related to sedimentation of fine

21 glacial sediments corresponding to the general position of the seasonal sediment plume

22 from glacial runoff in the fjord (Fig. 1) (Feder and Matheke, 1980; Feder and Jewett, 23 1988).

24 A magnitude 9.2 earthquake in March, 1964, caused catastrophic disturbances to

25 all marine communities in PWS (Haven, 1971; Hubbard, 1971; Stanley, 1968). The

26 intertidal and subtidal benthic communities of the study area were impacted by scouring

27 from the tsunamis and catastrophic sediment slumping (Coulter and Migliaccio, 1971;

28 McRoy, 1988; Sharma and Burbank, 1973; Naidu and Klein, 1988). Displaced sediments

29 were deposited in the basin of Port Valdez, directly impacting benthic organisms through 30 burial. 
Anthropogenic stresses on the marine environment in Port Valdez increased

2 greatly over the 35-year investigation (McRoy, 1988). As the northernmost, ice-free port

3 available for large vessel traffic, Port Valdez was selected to be the site of the marine oil

4 terminal serving as the terminus for the Trans-Alaska pipeline which became

5 operational in 1977. Discharge of treated ballast water from the oil terminal is a

6 continuing stress to some shallow-water biological communities adjacent to the oil

7 terminal (Blanchard et al., 2002, 2003). Oily ballast water is unloaded from tankers at

8 the oil terminal, treated onshore to remove hydrocarbons, and discharged into the fjord

9 through a diffuser pipe at $60 \mathrm{~m}$ to $80 \mathrm{~m}$ depth. Discharges are decreasing due to the

10 declining volume of oil transported (Blanchard et al., 2002; Richardson and Erickson,

11 2005). A salmon hatchery located on the south side of the fjord, downstream from the oil

12 terminal, began commercial operations in 1982 with first returns in 1983. Over 200

13 million salmon fry are now raised and released every year with returns of more than 10

14 million adult fish (predominantly pink salmon Oncorhynchus gorbuscha) (White, 2008).

15 There are too many returning adult salmon to fully harvest, so many salmon die in the

16 fjord and their carcasses are deposited in the intertidal or settle on subtidal sediments.

17 Growth of the City of Valdez and associated urban development altered nearshore

18 habitats largely through urban development and industrialization such as construction of

19 roads, docks, and a gas refinery (Wiegers et al., 1998; Blanchard and Feder 2003).

20 Ecosystem stress in the fjord increased through various means including urban discharges

21 and uncontrolled urban runoff, habitat alterations, increased marine vessel traffic, and

22 continuing nearshore development (McRoy, 1988; Wiegers et al., 1998; Blanchard and

23 Feder, 2003).

25 3. Methods

26 Subtidal fauna were first sampled in Port Valdez in 1971. Six stations sampled

27 over the study period comprise a transect down the center of the fjord with three replicate

28 samples collected at sites on the transect in September 1971 and generally five from late

29 summer to fall in 1976-1977, 1980 to $1982,1985,1987$ and annually since 1989 to 2007

30 (not all sites were sampled every year) (Fig. 1). This transect encompasses a gradient in

31 sedimentation rates and environmental processes from the head of the fjord (where 
1 glacial rivers enter the fjord and suspended sediments are highest) to the fjord mouth.

2 Sediment for faunal samples was collected with a van Veen grab $\left(0.1 \mathrm{~m}^{2}\right)$, washed over a

$31.0 \mathrm{~mm}$ screen, and fauna preserved in $10 \%$ buffered formalin. Macrofauna (infaunal

4 invertebrates retained on $1.0 \mathrm{~mm}$ mesh sieve) were identified to the lowest taxonomic

5 level practical, mostly to genera or species, counted, and weighed. Faunal identifications

6 were aggregated to the family level or higher for all analyses because of taxonomic

7 uncertainties and changes in identifications from the early years of the study (1971-1980)

8 to the present. While analysis of more detailed taxonomic information is preferable, the

9 loss of information due to aggregation to family is not too great and ecologically relevant

10 trends will still be apparent (Feder and Blanchard, 1998; Wlodarska-Kowalczuk and

11 Kedra, 2007). Species identifications are noted in the text where possible. In 2002, field

12 sampling also included occupation of many sites from the fjord-wide grid established in

131971 (Fig. 1).

14 Faunal measures calculated include average abundance (individuals $\mathrm{m}^{-2}$ ), wet

15 weight biomass $\left(\mathrm{g} \mathrm{m}^{-2}\right)$, and total number of taxa (includes family or unique higher

16 taxonomic categories). Average abundance and biomass for each year represent the

17 averages for stations on the deep-basin transect for each year. The tabulated statistic total

18 number of taxa was calculated as the number of taxa found within a year (over all stations

19 combined) whereas geostatistical modeling relied on the number of taxa per station per

20 year.

21 Nonmetric multidimensional scaling (MDS) was used to elucidate community-

22 level changes in family abundance estimates over time. To assess the changes in the

23 faunal relationships, surveys from 1971, 1976, 1981, 1985, 1990, 1995, 2000, and 2005

24 were analyzed. Bray-Curtis similarity coefficients (Bray and Curtis, 1957) were

25 calculated between the individual stations for each year using $\ln (X+1)$-transformed mean

26 family abundance. MDS was applied to the resulting similarity matrices using the

27 PRIMER software package to assess similarities of stations between years (Clarke and

28 Gorley, 2001). The ANOSIM routine tested for differences between years and the

29 eastern and western stations (as determined by Feder and Matheke, 1980). The SIMPER

30 routine of PRIMER was used to determine contributions of individual taxon categories to

31 year groups. 
1 Inclusion of the fjord-wide sites sampled in 1971 and 2002 allowed for direct

2 comparisons to be made in the abundance and distribution of selected families. Bubble

3 plots and bar charts of the abundance with $95 \%$ confidence intervals of the selected fauna

4 were generated to assess changes in the distributions of fauna. Two-way ANOVA was

5 used to assess differences between years and eastern and western fjord stations.

6 Spatio-temporal modeling was applied to assess changes over space and time in

7 macrofauna abundance, biomass and the number of taxa (Stein et al., 1998). The

8 statistical program R (www.r-project.org) and the spatial tools in the library GeoR

9 (Ribeiro and Diggle, 2001; http://cran.r-project.org/) were used to perform geostatistical

10 analysis of the biotic variables. The data were average abundance, biomass, and number

11 of taxa for each station by year. Only those stations on the transect along the center of

12 the fjord were used for spatio-temporal modeling (Fig. 1). The suite of stations sampled

13 over time represents a one-dimensional measure of distance so distance and time were

14 used to model changes in faunal parameters. The correlation structures of the variables

15 were modeled with the spherical model (Cressie, 1993). Abundance values were

$16 \ln (\mathrm{X}+1)$-transformed and biomass $\ln (\mathrm{X})$-transformed to meet the assumption of normal

17 errors and all data were detrended by modeling trends as a polynomial functions of

18 distance and year. Contour plots of back-transformed predicted values from the spatial

19 models are presented.

20 Spearman's nonparametric correlation coefficient was used to determine

21 associations between biotic variables and measures of anthropogenic stress, weather

22 variables, and a climatic index. Biological indices used include average abundance and

23 biomass, and total number of taxa per year. Available measures of anthropogenic stress

24 were salmon fry releases (1982-2007), adult salmon returns (1983-2007), and average

25 total aromatics (PAH: 1976, 1977 (different deep stations for 1976 and 1977 but also

26 representing a transect down the fjord), 1980-1982, 1985, 1989-2007). The data on

27 salmon fry releases and adult returns were from annual reports to the State of Alaska

28 (Alaska salmon enhancement program annual reports available through Alaska Dept.

29 Fish and Game, Juneau, AK; e.g., White, 2008) and data for PAH (the sum of 18

30 polycyclic aromatic hydrocarbons) were from the long-term monitoring study in Port

31 Valdez (Blanchard et al., 2002) (Table 1). Measures of weather and regional climatic 
1 variability include average annual temperature, total precipitation, and annual snowfall

2 from the Valdez weather station (http://climate.gi.alaska.edu/) and the yearly average of

3 the Pacific Decadal Oscillation index (PDO) (www.aoss.org). The PDO reflects

4 anomalies in sea surface temperature (with positive anomalies representing warmer

5 water) and is a measure of climatic variability strongly associated with ecological

6 processes and faunal changes in the northern Pacific ocean (Mundy and Spies, 2005;

7 Pinchuk et al., 2008).

9 4. Results

10 A total of 11 phyla encompassing 77 families were identified. Polychaetes and

11 bivalves comprised $64 \%$ and $22 \%$ of the total numbers of individuals, respectively, for all

12 years combined. The highest abundance occurred in 1987 with an average of 589 ind. m

$13{ }^{2}$, the highest biomass value was in 2005 with $33.79 \mathrm{~g} \mathrm{~m}^{-2}$, and the highest total number

14 of taxa (family or greater) across the transect occurred in 1997 with 52 taxon categories

15 followed by 1976 with 51 categories recorded (Table 1). The lowest abundance was in

161980 with 156 ind. $\mathrm{m}^{-2}$, lowest biomass was in 1985 with $7.02 \mathrm{~g} \mathrm{~m}^{-2}$, and the lowest

17 number of taxa was in 1971 with 29 taxon categories identified.

18 The MDS ordination suggested a high level of similarity among years and

19 sampling locations (Fig. 3). Nevertheless, separations by year were apparent as sampling

20 locations for 1971 and 1976 grouped by year while stations for 1981 and 1985 were

21 mixed together forming a separate group, as was also true for 1990 to 2005. ANOSIM

22 indicated that the year groupings were significant as the overall $\mathrm{R}=0.563(\mathrm{p}=0.001)$.

23 The multiple comparisons supported the observed groupings with $\mathrm{R}=0.159(\mathrm{p}=0.084)$

24 for the comparison between 1981 and 1985 suggesting weak differences at most, $\mathrm{R} \leq$

$250.169(\mathrm{p} \geq 0.212)$ for comparisons between the years 1990 to 2005 indicating no

26 differences between years, and $R \geq 0.426(\mathrm{p} \leq 0.036)$ indicating highly significant

27 differences for all other comparisons. The MDS ordination also supported an additional

28 separation of eastern and western fjord stations (as subgroups) as the ANOSIM overall $\mathrm{R}$

$29=0.583(\mathrm{p}=0.001)$ for an overall comparison of east vs. west stations (see Fig. 1 for

30 definition of division boundaries). Support from multiple comparisons was weaker due

31 to sample size limitations. For the east vs. west comparison by year, $\mathrm{R}=0.583$ for 1971 
1 (small sample with too few permutations for accurate determination of the p-value), $\mathrm{R}=$

20.583 for 1976 (small sample), $\mathrm{R}=0.319(\mathrm{p}=0.011$ ) for 1981 to 1985 , and $\mathrm{R}=0.248$ ( $\mathrm{p}$ $3=0.033$ ) for 1990 to 2005 .

$4 \quad$ Numerically dominant families determined by SIMPER for the multivariate year

5 groupings demonstrated large temporal changes. In 1971, dominant species in the fjord

6 included the polychaete family Capitellidae (frequently Heteromastus filiformis), a family

7 known for opportunistic behavior, which comprised $21 \%$ and $34 \%$ of overall abundance

8 in 1971 and 1976, respectively, with abundance dropping to $6 \%$ of total abundance in

91981 and 1985 and 7\% in 1990 to 2005 (1990, 1995, 2000, and 2005) (Fig. 3). The

10 polychaete family Spionidae was moderately abundant in 1971 comprising $12 \%$ of

11 overall abundance but was infrequent in later years as abundance was $1 \%$ or less of total

12 abundance in 1976 and later. Cumaceans of family Leuconidae (largely Eudorella

13 emarginata) comprised 11\% of abundance in 1971, 7\% in 1976, and 2\% from 1981 to

14 2005. The abundance of polychaetes of family Lumbrineridae (Lumbrineris spp. and

15 Ninoe gemmea) was moderate in 1971 comprising 9\% of total abundance, higher in 1976

16 at $11 \%$ of total abundance but declined to $4 \%$ in 1981 and 1985 and 6\% in 1990 to 2005.

17 Bivalves of family Thyasiridae (Adontorhina cyclia, Axinopsida serricata, and

18 infrequently, Thyasira flexuosa) were not abundant in 1971 comprising only $2 \%$ of

19 abundance but increased to 7\% in 1976, 24\% in 1981 and 1985, and 18\% in 1990 to

20 2005. The polychaetes Oweniidae (primarily Galathowenia oculata) and

21 Trichobranchidae (mostly Terebellides stroemi) were absent from the survey transect in

22 1971. Oweniid polychaetes were also absent in 1976 but present in 1981 and 1985 with

$234 \%$ of total abundance and 6\% in 1990 to 2005. Polychaetes of family Trichobranchidae

24 were 4\% of total abundance in 1976, 8\% in 1981 and 1985, but only 2\% in 1990 to 2005.

25 The polychaete family Nephtyidae (numerically dominated by Nephtys punctata) was

26 present all years in moderate abundance comprising $10 \%$ of total abundance in 1971, 4\%

27 abundance in 1976, 4\% of total abundance in 1981 and 1985, and 6\% total abundance in 281990 to 2005 .

29 Changes in abundance and distributions of selected macrofauna families

30 demonstrated significant changes over time between the stations sampled over the whole

31 of the fjord in 1971 and 2002. Bubble plots of abundance demonstrate that the 
1 polychaetes Maldanidae, Paraonidae, and Trichobranchidae were sparse in the fjord in

21971 but abundant and distributed throughout the fjord in 2002 (Fig. 4). The bivalves

3 Thyasiridae occurred throughout the fjord in 1971 but in low abundance, as compared to

4 2002. The change in abundance for these taxon groups represents a 15-fold increase in

5 abundance from 1971 to 2002 for Maldanidae and 8-fold, 13-fold, and an 8-fold increases

6 for Paraonidae, Trichobranchidae, and Thyasiridae, respectively. Two-way ANOVA

7 indicated significantly lower abundance values in 1971 than in 2002 for Maldanidae,

8 Trichobranchidae, and Thyasiridae (Fig. 4). Average abundance of Paraonidae was

9 significantly lower for the western stations than for the eastern sites and in 1971 as

10 compared to 2002. The cumacean family Leuconidae (mostly Eudorella emarginata)

11 was abundant in most of the fjord in 1971 with lower abundance in the eastern fjord but

12 in 2002, the cumaceans were more abundant along the margins of the fjord than in the

13 basin (Fig. 4). Leuconidae abundance in 1971 was 2 times that of the abundance found in

142002 with significantly higher abundance at the western stations in 1971 as compared to

15 the other categories. Ophiuroids (mostly Ophiura sarsi) were common in 1971 in the

16 western deep basin but were absent in 2002 (Fig. 4). In both years, the ophiuroid family

17 Amphiuridae was moderately abundant at a few sites and particularly abundant adjacent

18 to a small, outwash delta on the southern edge of the fjord. One polychaete family,

19 Oweniidae (largely G. oculata) demonstrated particularly dramatic temporal changes in

20 distribution. Although oweniid polychaetes were absent from the deep basin of the fjord

21 in 1971, they occurred in very low abundance at one site in Valdez Arm just outside the

22 fjord (Fig. 5). Comparisons of rank-transformed abundance indicated significant

23 differences between 1971 and 2002. Oweniid polychaetes were still relatively

24 uncommon in 1976, more common in 1982, and by 2002, they were a dominant member

25 of the benthic community.

26 Spatio-temporal modeling demonstrated significant trends in abundance, biomass, 27 and the number of taxa from 1971 to 2007. The kriging plot (the graphic summary of

28 the spatio-temporal model) for abundance indicated increasing abundance over time and

29 with distance from the west (station 50 near the mouth of the fjord: $0 \mathrm{~km}$ ) to the east

30 (station 11 near the head of the fjord: $14 \mathrm{~km}$ ) with low abundance indicated in the lower

31 left of the plot by orange and yellow and high values in the upper right corner shown in 
1 blue and purple (Fig. 6). The whisker plot by year demonstrated more variable

2 abundance through 1990 ( $\mathrm{SD}=139.1$ ind. $\mathrm{m}^{-2}$ based on overall means; Table 1), as

3 compared to 1991 to 2007 ( $\mathrm{SD}=77.1$ ind. $\mathrm{m}^{-2}$ ), with significantly lower values (shown

4 by the non-overlapping confidence intervals) generally occurring from 1971 to 1990 and

5 an overall trend of increasing abundance. The whisker plot by distance indicates

6 significantly lower abundance mid-fjord and significantly higher abundance at distances

$7 \quad>11 \mathrm{~km}$. The kriging plot and the whisker plot by distance for biomass demonstrated

8 decreasing values with increasing distance from the west end of the fjord (Fig. 7). The

9 whisker plot of biomass grouped by year showed a negligible increase in biomass over

10 time and negligible differences in variance from 1971 through $1990\left(\mathrm{SD}=7.4 \mathrm{ind} . \mathrm{m}^{-2}\right.$ )

11 compared to 1991 to 2007 ( $S D=5.3$ ind. $\mathrm{m}^{-2}$ ). For the number of taxa, the kriging and

12 whisker plots demonstrated increasing number of taxa over time, with a sharp increase in

13 the number of taxa from 1985 through 2007, and decreasing values with distance west to

14 east (Fig. 8). The difference in variability in the number of taxa was negligible from

151971 to $1990\left(\mathrm{SD}=8.0\right.$ ind. $\left.\mathrm{m}^{-2}\right)$, as compared to later years $\left(\mathrm{SD}=6.6\right.$ ind. $\left.\mathrm{m}^{-2}\right)$.

16 Correlation analysis indicated moderate relationships between faunal measures

17 and indices of environmental change. Moderate correlations were observed between

18 biomass and salmon fry releases and adult returns ( $\rho=0.350$ and 0.399 , respectively) and

19 the average PDO and abundance and biomass $(\rho=0.377$ and -0.311 , respectively; Table 2

20 and Fig. 9). Negligible to small correlations were observed between releases and returns

21 and abundance ( $\rho=0.229$ and 0.119 , respectively) and the number of taxa ( $\rho=-0.269$ and

$22-0.244$, respectively). Correlations between PAH and the biological variables were also

23 negligible to small ( $\rho=0.049$ to 0.292 ). Correlations between local climatic measures

24 were small for average precipitation and biomass $(\mathrm{p}=-0.280)$, average temperature and

25 abundance $(p=0.250)$, and total snowfall and biomass $(\rho=0.257)$.

27 5. Discussion

285.1 Influences of Environmental Gradients in Fjords and Climatic Variability

29 The macrofauna assemblage in the deep basin of Port Valdez is characteristic of

30 fauna found in glacial fjords worldwide. Deposit-feeding polychaetes are dominant in 
1 the study area, as found in glacial fjords elsewhere, including the surface-deposit feeding

2 owenid polychaete Galathowenia oculata, spionid polychaetes (Polydora spp. and

3 Prionospio spp.), and subsurface-deposit feeding polychaetes Heteromastus filiformis

4 (family Capitellidae) and family Maldanidae (Gulliksen et al., 1985; Holte, 1998;

5 Wlodarska-Kowalczuk et al., 1998; Feder and Blanchard, 1998, Burd et al., 2000; Hoberg

6 and Feder, 2002; Ríos et al., 2005). Deposit-feeding bivalves found in Port Valdez are

7 also common in northern-hemisphere glacial fjords including the families Nuculanidae

8 (Megayoldia/Yoldia spp. and Nuculana sp.) and Thyasiridae (Axinospida spp. and

9 Thyasira spp.) (Holte, 1998). The dominance of deposit-feeding animals is the result of

10 the inability of most surface-dwelling fauna to adjust to the reduced availability of carbon

11 fluxing to the bottom and high sedimentation rates (Görlich et al., 1987; Holte et al.,

12 1996; Wlodarska-Kowalczuk and Pearson, 2004; Renaud et al., 2007). The combined

13 influence of seasonal stratification, seasonality of production, early consumption of

14 water-column primary production by zooplankton, and dilution of food by glacial

15 sediments contribute to the paucity of carbon in benthic systems of glacial fjords (Sargent

16 et al., 1983; Cooney and Coyle, 1988; Oug, 2000). Lack of carbon reaching the benthos

17 in Port Valdez was evident in the low estimate for annual macrofaunal production ( 0.3 to

$181.7 \mathrm{~g} \mathrm{~m}^{-2} \mathrm{yr}^{-1}$ ) (Feder and Jewett, 1988) and low abundance and biomass (Table 1).

19 Macrofauna in glacial fjords are stressed by high sedimentation rates resulting in

20 strong gradients in community structure (Holte and Gulliksen, 1998; Wlodarska-

21 Kowalczuk et al., 2005). A common trend of increasing abundance and diversity with

22 lower biomass towards the head of a fjord reflects the increased proportions of small

23 disturbance-tolerant organisms and the greater stress found near sources of glacial

24 sediments (Holte and Gulliksen, 1998; Wlodarska-Kowalczuk and Pearson, 2004;

25 Wlodarska-Kowalczuk et al., 2005). The general spatial trend associated with

26 sedimentation rates and fine sediments was observed in prior studies of Port Valdez

27 (Feder et al., 1973; Feder and Jewett, 1988; Naidu and Klein, 1988) where, as also

28 indicated by spatio-temporal modeling in the present study, communities in the western

29 end had higher number of taxa and biomass and lower abundance compared to the faunal

30 assemblage of the eastern end (closest to the major sources for glacial sediments). The

31 major faunal trend in van Mijenfjord, a silled fjord in Spitsbergen, reflected disturbance 
1 from fine sediments, and gradients in faunal communities were similar between 1980 and

22001 (Wlodarska-Kowalczuk et al., 2005; Renaud, et al., 2007). Like van Mijenfjord,

3 little temporal change in community structure was reported for Balsfjord, Norway

4 although minor increases in abundance were noted, possibly a result of changes in the

5 composition of pelagic fauna and grazing rates (Oug, 2000). In general, the physical

6 characteristics and sediment gradients in glacial fjords result in the temporal and spatial

7 persistence of gradients in benthic faunal community structure as well.

8 The Pacific decadal oscillation (PDO) is an index of climate variability associated

9 with ecologically-important changes in physical processes of the North Pacific Ocean and

10 nearshore coastal waters. The PDO contrasts sea surface temperatures between the

11 Central and Northeast Pacific such that when the PDO is positive, sea surface

12 temperatures are elevated in the coastal Northeast Pacific (Royer et al., 2001). The

13 warmer waters of a positive PDO leads to increased rainfall and greater coastal

14 freshwater flow along the Northeast Pacific which may have a number of effects on the

15 ecosystem including strengthening of stratification in the water column in summer (Neal

16 et al., 2002; Mundy and Cooney, 1995; Weingartner et al., 2005). Increased stratification

17 of the water column will initially result in greater primary production but may prevent

18 mixing of nutrients upward from deep water later (Royer et al., 2001). Shifts in

19 ecological processes associated with the PDO variations may influence benthic fauna in

20 Prince William Sound (PWS) and Port Valdez through changes in the timing and volume

21 of annual primary production, grazer availability, grazing rates, flux of nutrients to the

22 benthos, and processes influencing larval survival (Mundy and Cooney, 1995; Beuchel et

23 al., 2006).

24 Fauna in the deep basin (>150 m) of Port Valdez appear to be sensitive to

25 decadal-scale climatic variability although the pathways through which the PDO may

26 have influenced fauna are unknown. Relationships between the PDO and macrofauna are

27 suggested by the moderate associations of faunal summary measures and the PDO index

28 in Port Valdez ( $\rho=0.38$ and -0.31 , for abundance and biomass, respectively; Table 2 ).

29 The association between abundance and the PDO index were strongest from 1987 to

302007 with less apparent association from 1971 to 1987 when the benthos was recovering

31 from the 1964 earthquake (Fig. 9) (see discussion below). Most primary production of 
1 Alaskan glacial fjords reaches deep sediments through undigested matter in zooplankton

2 fecal pellets with most production occurring in the spring before glacial melt waters

3 reduce visibility (Cooney and Coyle, 1988; Burrell, 1983). This provides one potential

4 pathway for climatic variability to affect benthic communities as greater rainfall

5 associated with positive PDO values may result in a greater snowpack in surrounding

6 mountains. The increased spring runoff may then enhance stratification resulting in

7 greater spring primary production (Mundy and Cooney, 1995; Royer et al., 2001) and

8 consumption of the increased production by zooplankton and fall of fecal pellets to the

9 bottom would then enhance survival of new recruits in the benthos. Benthic community

10 structure may also be directly influenced by interactions between water temperature and

11 survival of pelagic larvae (Barnett and Watson, 1986; Pearson et al., 1986).

12 The temporal stability of community structure in a protected, silled-fjord in

13 Spitsbergen (with tidewater glaciers) suggested that benthic fauna were largely

14 influenced by interactions between local hydrography, physical characteristics, and

15 faunal life-history traits and may be resistant to decadal-scale environmental variability

16 (Renaud et al., 2007). Like the macrofauna of Spitsbergen (with tidewater glaciers), the

17 overall community structure of macrofauna in the basin of Port Valdez has not shown

18 great change since 1990 (see discussion below) since overall faunal composition is

19 controlled by the ecological characteristics of the fjord. However, the present study does

20 suggest that fauna in deep basins can be responsive to regional environmental trends

21 through changes in other facets of community composition (abundance and biomass).

22 The increased volume of glacial melt waters and runoff in warmer years from the large

23 watershed in the Chugach Mountains surrounding Port Valdez (a glacial outwash fjord)

24 (which would be absent or reduced in fjords with tidewater glaciers) is likely the source

25 for effects on benthic fauna at depth (>150 m). Thus, sensitivity to climatic change in

26 nearshore communities may be dependent on landscape-scale factors of surrounding

27 watersheds rather than just interactions of oceanographic and biological features within a 28 fjord.

29

$30 \quad 5.2$ Effects of the Great Alaska Earthquake in 1964 
The greatest perturbation in Port Valdez in recent history was a magnitude 9.2

2 earthquake in PWS March, 1964. The earthquake was so great as to have impacted every

3 marine community in PWS by topographic changes, scouring by tsunamis, and sediment

4 slumping and resuspension (Coulter and Migliaccio, 1971; NRC, 1971). The deep

5 benthos in Port Valdez was disrupted by the mass sediment slumping triggered by the

6 earthquake and deposition of sediments over the bottom (Coulter and Migliaccio, 1971;

7 Sharma and Burbank, 1973; Feder and Jewett, 1988; Naidu and Klein, 1988). Effects of

8 the catastrophic disturbance in Port Valdez were reflected in differences of community

9 structure among years in the multivariate analyses, the temporal changes in abundance

10 and distributions of fauna, and spatio-temporal modeling (Fig. 3). Additionally,

11 moderately increased variability in abundance (a symptom of disturbance) was apparent

12 for Port Valdez from 1971 to 1989 as also occurred following cessation of sewage-sludge

13 disposal in Liverpool Bay, UK (Fig. 6) (Warwick and Clarke, 1993; Whomersley et al.,

14 2007). The much weaker association of faunal abundance to the PDO index from 1971 to

151989 is additional evidence for the presence of a strong, ecological process in the benthos

16 related to faunal readjustment from the earthquake rather than climate effects (Fig. 9).

17 Since there are no published studies of long-term trends in benthic fauna following a

18 physical disturbance of a magnitude or scale comparable to the 1964 earthquake in PWS,

19 it is difficult to discern to what extent physical characteristics of Port Valdez contributed

20 to delayed recruitment. However, interactions between fauna and physical factors can be

21 expected to influence temporal trends of faunal assemblages since readjustment is

22 determined to yarying degrees by hydrodynamics, circulation patterns or restrictions, and

23 other physical features (e.g., Hall, 1994; Molinet et al., 2006).

24 Faunal readjustment from large disturbances can be a lengthy process in glacial

25 fjords. The benthic community in disturbed sediments in Alice Arm, a silled fjord in

26 British Columbia disturbed by mining activities, was dominated by disturbance-tolerant

27 species until disturbance abated (Burd et al., 2000). Although considerable faunal

28 readjustment occurred three years after cessation of tailing disposal, up to 18 years was

29 required for biota to return to the ambient faunal community in Alice Arm. Faunal

30 changes included introductions of numerous species into disturbed locations where they

31 became dominant members of the macrofaunal assemblage. Initial colonizers responded 
1 quickly to cessation of disturbance but recruitment of stress-intolerant species was

2 delayed (Burd et al., 2000). The temporal trends in Port Valdez were similar in scope to

3 readjustment patterns of fauna in Alice Arm suggesting that large-scale recolonization

4 occurred, as would be expected following a very large earthquake. In the present study,

5 the absence or low abundances of Maldanidae, Oweniidae, Paraonidae and Thyasiridae in

61971 and subsequent redistributions were striking since these organisms are common in

7 muddy sediments in Prince William Sound (PWS) (Figs. 4 and 5) (Feder and Blanchard,

8 1998; Hoberg and Feder, 2002). Additionally, spatio-temporal modeling indicated that

9 the number of taxa and abundance increased over time, as would be expected following

10 disturbance (Figs. 6 and 8) (Boesch and Rosenberg, 1981; Burd et al., 2000).

11 Disturbance to the faunal assemblage was also suggested by the relative dominance of

12 Capitellidae, a disturbance-tolerant, opportunistic polychaete family, in 1971 and 1976

13 (Fig. 3). Evidence from faunal trends and spatio-temporal modeling indicates that the

14 macrofaunal assemblage in the basin of Port Valdez reached a point of stability in 1990,

1526 years after the 1964 earthquake.

16 Temporal persistence of effects from physical disturbance on benthic systems is

17 dependent on the scale of disturbance, larval and adult recruit supplies, pre and post-

18 settlement processes for recruits, and other factors (Hall, 1994). Recovery can be rapid

19 when new recruits and adults are readily available even when disturbance is large

20 (Boesch and Rosenberg, 1981; Snelgrove and Butman, 1994; Reise, 2002; Gimenez,

21 2004). In fjords, however, seasonal stratification of the water column and restriction of

22 deep-water movement by sills in fjords may contribute to the slow recolonization of

23 benthic organisms. The sills of glacial fjords like Port Valdez interfere with larval

24 transport and recruitment, thereby preventing some larvae from reaching the deep basin

25 while sluggish water movement may slow their dispersal within the basin (Muench and

26 Nebert, 1973; Colonell, 1980a; Burd et al., 2000; Molinet et al., 2006). As a result, it

27 can be difficult to predict recovery processes or the time frame required for benthic

28 communities to return to prior environmental conditions and ambient faunal assemblages

29 in fjords. Interactions between fauna, climate variations, and physical characteristics may

30 be even more important when mature fauna are unavailable for larval production and

31 larvae must come from distant sources as might occur with a very large, landscape-scale 
1 perturbation. Such a large reduction of mature, reproducing macrofauna populations may

2 have occurred in PWS following the 1964 earthquake, as suggested by the reduced

3 abundance of fauna in 1971 and delayed recruitment of some otherwise ubiquitous

4 polychaetes in Port Valdez.

\section{$6 \quad 5.3$ Anthropogenic Stressors}

$7 \quad$ Migratory salmon are an important link between oceans, estuaries, and watersheds

8 wherever they occur (Kline et al., 1990, 1993; Finney et al., 2000; Naiman et al., 2002;

9 Ray, 2005). Evidence for a fjord-wide influence of salmon released from a shoreline

10 hatchery in Port Valdez includes the positive correlations of salmon releases and returns

11 with macrofauna biomass shown in this study ( $\rho=0.35$ and 0.40 , respectively) and the

12 ubiquitous presence of fish bones and otoliths in sediment from the deep benthos (Table

13 2; A. L. Blanchard, personal observations). The large number of juveniles released into

14 Port Valdez undoubtedly influence benthic systems by feeding on zooplankton thereby

15 altering pathways of energy exchange between ecosystem components with unknown

16 effects on the benthic components of marine ecosystems. Carcasses of adult salmon may

17 directly influence benthic communities by providing an immediate food source for

18 scavenging macrofauna but most carcasses are likely deposited intertidally or in the

19 shallow subtidal with fewer reaching the deep benthos so the pathways through which

20 carcasses may influence fauna in the basin of a fjord are not entirely clear. In freshwater

21 systems, nutrients from salmon carcasses (dissolved or particulate marine-derived

22 nutrients) are dispersed through numerous ecosystem components and multiple pathways

23 (Naiman, 2002; Ray, 2005). Similarly, dissolved nutrients and particulates released by

24 decomposing salmon from the intertidal and shallow subtidal are likely to be dispersed

25 throughout a fjord. Particulate organics and dissolved nutrients indirectly reaching the

26 benthos (e.g., transfers of particulates through water layers as opposed to direct carcass

27 falls) would be available to deposit-feeding organisms in the basin of Port Valdez and the

28 lack of scavenging organisms in the deep benthos suggests that such indirect transfers

29 may be greatest. While the exact pathways for energy and nutrient flow of salmon carcass

30 decomposition products to the deep basin are unknown for Port Valdez, the evidence 
1 suggest that a moderate flow (likely through multiple, indirect pathways) is present, as

2 shown from studies of freshwater systems (Naiman, 2002; Ray, 2005).

3 The correlative evidence for associations between faunal measures from the deep

4 basin of Port Valdez and salmon releases and returns suggests small effects at most rather

5 than large changes like the gross organic enrichment caused by fish farming and

6 eutrophication elsewhere (Josefson and Rosenburg, 1988; Muslow et al., 2006).

$7 \quad$ Dominance by opportunistic species or complete loss of species resulting from organic

8 enrichment was not observed in the deep basin of Port Valdez, although deposition of

9 fish wastes from a processing plant adjacent to the City of Valdez led to such conditions

10 in a limited shallow subtidal area (Blanchard and Feder, 2003). Given the tendency for

11 increasing stress in coastal waters (Schiff et al., 2000), effects from hatchery salmon fry

12 releases ( 200 million annually) and returns ( 10 million annually) (White, 2008$)$ in Port

13 Valdez could lead to large interactions in the future with other stressors and potentially

14 stronger, negative effects.

15 Effects from discharge of treated tanker ballast water from a treatment plant at the

16 marine oil terminal in Port Valdez were not observed in the deep basin. In the present

17 study, average sediment PAH concentrations in the deep basin were low and below

18 concentrations expected to result in alterations of faunal communities (Leung et al.,

19 2005). Hydrocarbon accumulations and associated effects on fauna of Port Valdez are

20 limited as most hydrocarbons are diluted within the water column due largely to the steep

21 slope where hydrocarbons are discharged, depth of the fjord, oceanography, and low

22 quantities of organics in sediment to which hydrocarbons may adsorb (Shaw, 1988).

23 Spatially and temporally limited effects associated with increased PAH were observed in

24 shallower waters within a few hundred meters of the point of discharge of treated ballast

25 water but similar trends in fauna (e.g., increases or gradients in hydrocarbon-tolerant

26 species near the oil terminal) were not noted for deep basin communities (Shaw, 1988;

27 Blanchard et al., 2002, 2003). As indicated by Wake (2002), interactions between

28 effluents and the physical environment are important in the fate of hydrocarbons

29 discharged into the marine environment and with adequate treatment, residual

30 hydrocarbons have very limited effects. Effects of hydrocarbons on fauna in Sullom

31 Voe, Shetland Islands, were strongly influenced by interactions with environmental 
1 gradients and effects were reduced where accumulations were prevented by

2 hydrodynamics (although hydrocarbon deposition and associated effects increased at sites

3 with greater organics) (May and Pearson, 1995). The lack of effects from hydrocarbons

4 in the deep basin of Port Valdez was likewise due to a combination of physical

5 characteristics, oceanography, and treatment of wastes at the ballast-water treatment

6 facility (Shaw, 1988).

8 6. Conclusions

9 Trends observed in Port Valdez from 1971 to 2007 suggest an ecosystem in flux.

10 Although the macrofaunal assemblage in the deep basin was generally similar to that of

11 glacial fjords elsewhere, trends in faunal abundance and community structure deviated

12 significantly from the stability expected for glacial fjords. Natural factors were the

13 strongest drivers of spatial and temporal change. Effects on biotic communities from the

14 catastrophic disturbance of the 9.2 magnitude earthquake in 1964 were large and faunal

15 readjustment was the dominant source of variability in the deep benthos from 1971 to

16 1989. The readjustment process was demonstrated through introductions and subsequent

17 dispersal of macrofauna families in the basin and trends in the spatio-temporal models.

18 Following readjustment from the earthquake, long-term climatic trends were important

19 sources of variability for benthic fauna from 1989 to 2007. Spatial trends in faunal

20 indices were associated with the sediment gradient from the head to the mouth of the

21 fjord as well. Physical characteristics of the fjord (e.g., the sills, basin depth, limited

22 water movement in the basin, and sedimentation rate) were important structuring factors

23 of faunal communities spatially and temporally during the period of faunal readjustment.

24 Releases of juvenile salmon at the hatchery since 1982 and returns of adult salmon were

25 positively associated with macrofaunal biomass suggesting enhancement of the deep

26 benthic fauna. The Valdez marine oil terminal does not measurably contribute to faunal

27 variations in the deep basin largely due to the fjord's physical and oceanographic

28 characteristics. Overall, benthic communities in the deep basin were in a state of flux up

29 to 1990 while a state of greater stability was reached in 1990 that more closely reflected

30 the stability observed in fjord-basin fauna of undisturbed fjords elsewhere. 
7. Acknowledgements.

2 This work was supported by continuing grants from Alyeska Pipeline Service Co.

3 to Drs. A. L. Blanchard, H. M. Feder and D. G. Shaw. We thank the many technicians

4 who have contributed to this project. We thank Maria Wlodarska-Kowalczuk and an

5 anonymous reviewer for their constructive comments.

8. References

8 Austen, M.C., Buchanan, J.B., Hunt, H.G., Josefson, A.B., Kendall, M.A., 1991.

9 Comparison of long-term trends in benthic and pelagic communities of the North Sea.

10 Journal of the Marine Biological Association of the UK 71, 179-190.

11 Barnett, P.R.O., Watson, J., 1986. Long-term changes in some benthic species in the Firth

12 of Clyde, with particular reference to Telinna tenuis da Costa. Proceedings of the

13 Royal Society of Edinburgh, 90B, 287-302.

14 Beuchel, F., Gilliksen, B., Carroll, M.L., 2006. Long-term patterns of rocky bottom

15 macrobenthic community structure in an Arctic fjord (Kongsfjorden, Svalbard) in

16 relation to climate variability (1980-2003). Journal of Marine Systems 63, 35-48.

17 Blanchard, A., Feder, H.M., 2003. Adjustment of benthic fauna following sediment

18 disposal at a site with multiple stressors in Port Valdez, Alaska. Marine Pollution

19 Bulletin 46, 1590-1599

20 Blanchard, A.L., Feder, H.M., Shaw, D.G., 2002. Long-term investigation of Benthic

21 Fauna and the Influence of Treated Ballast Water Disposal in Port Valdez, Alaska.

22 Marine Pollution Bulletin 44, 367-382.

23 Blanchard, A.L., Feder, H.M., Shaw, D.G., 2003. Variations of benthic fauna underneath

24 an effluent mixing zone at a marine oil terminal in Port Valdez, Alaska. Marine

25 Pollution Bulletin 46, 1583-1589.

26 Bray, J.R., Curtis, J.T., 1957. An ordination of the upland forest communities of Southern

27 Wisconsin. Ecological Monographs 27, 325-349.

28 Boesch, D.F., Rosenberg, R., 1981. Response to Stress in Marine Benthic Communities.

29 In: Barrett, G. W., and Rosenberg, R., (Eds.), Stress Effects on Natural Ecosystems.

30 John Wiley and Sons, Ltd, New York, pp. 179-198. Burd, B.J., 2002. Evaluation of

31 mine tailings effects on a benthic marine infaunal community over 29 years. Marine 
Environmental Research 53, 481-519.

2 Burd, B.J., Macdonald, R., Boyd, J., 2000. Punctuated recovery of sediments and benthic

3 infauna: a 19-year study of tailings deposition in a British Columbia fjord. Marine

4 Environmental Research 49, 145-175.

5 Burrell, D.C., 1983. Patterns of carbon supply and distribution and oxygen renewal in

6 two Alaskan fjords. Sedimentary Geology 36, 93-115.

7 Clarke, K.R., Gorley, R.N., 2001. User Manual/Tutorial. PRIMER-E Ltd., 91 pp.

8 Colonell, J.M., 1980a. Physical oceanography. In: Colonell, J.M. (Ed.), Port Valdez,

$9 \quad$ Alaska: Environmental Studies 1976-1979. Institute of Marine Science, University of

10 Alaska, Fairbanks, pp. 9-36.

11 Colonell, J.M., 1980b. (Ed.) Port Valdez, Alaska: Environmental Studies 1976-1979.

12 Institute of Marine Science, University of Alaska, Fairbanks.

13 Cooney, R.T., 1993. A theoretical evaluation of the carrying capacity of Prince William

14 Sound, Alaska, for juvenile Pacific Salmon. Fisheries Research 18, 77-87.

15 Cooney, R.T., Coyle, K.O., 1988. Water column production. In: Shaw DG, Hameedi MJ

16 (Eds.), Environmental studies in Port Valdez, Alaska. A basis for management.

17 Springer-Verlag, New York, pp. 93-116.

18 Coulter, H.W., Migliaccio, R.R., 1971. Effects at Valdez. In: National Research Council,

19 The Great Alaska Earthquake of 1964, Geology, Part A. National Academy of

20 Science, Washington, pp. 8-34.

21 Cressie, N.A.C., 1993. Statistics for spatial data. John Wiley and Sons, New York, pp.

22900.

23 Dojiri, M., Yamaguchi, M., Weisberg, S.B., Lee, H.J., 2003. Changing anthropogenic

24 influence on the Santa Monica Bay watershed. Marine Environmental Research 56, 114.

26 Feder, H.M., Blanchard, A., 1998. The deep benthos of Prince William Sound, Alaska,

27 sixteen months after the Exxon Valdez oil spill. Marine Pollution Bulletin 36, 118$28 \quad 130$.

29 Feder, H.M., Jewett, S.C., 1988. The subtidal benthos. In: Shaw, D.G., Hameedi, M.J.

30 (Eds.), Environmental studies in Port Valdez, Alaska. A basis for management.

31 Springer-Verlag, New York, pp. 165-202. 
1 Feder, H.M., Matheke, G.E.M., 1980. Subtidal benthos. In: Colonell, J.M., Stockholm, H.

2 (Eds.), Port Valdez, Alaska: Environmental Studies 1976-1979. Institute of Marine

3 Science, University of Alaska, Fairbanks, pp. 235-318.

4 Feder, H.M., Mueller, G.J., Dick, M.H., Hawkins, D.B., 1973. Preliminary benthos

5 survey. In: Hood, D.W., Shiels, W.E., Kelley, E.J. (Eds.), Environmental studies of

6 Port Valdez. Institute of Marine Science, University of Alaska, Fairbanks, pp. 3037391.

8 Finney, B.P., Gregory-Eaves, I., Sweetman, J., Douglas M.S.V., Smol, J.P., 2000.

9 Impacts of climatic change and fishing on pacific salmon abundance over the past

10300 years. Science 290, 795-799.

11 Gimenez, L., 2004. Marine community Ecology: importance of trait-mediated effects

12 propagating through complex life cycles. Marine Ecology Progress Series 283, 303-

$13 \quad 310$.

14 Görlich, K., Węsławski, J.M., Zająckowski, M., 1987. Suspension settling effect on

15 macrobenthos biomass distribution in the Hornsund fjord, Spitsbergen. Polar

16 Research 5, 175-192.

17 Gulliksen, B., Holte, B., Jakola, K.J., 1985. The soft bottom fauna in van Mijenfjord and

18 Raudfjord, Svalbard. In: Gray, J., Christiansen, M.E. (Eds.), Marine Biology of Polar

19 Regions and effects of stress on marine organisms. John Wiley and Sons, New York, 20 pp. 199-215.

21 Hall, S.J., 1994. Physical disturbance and marine benthic communities: life in

22 unconsolidated sediments. Oceanography and Marine Biology: an Annual Review 32,

$23 \quad 179-239$.

24 Haven, S.B., 1971. Effects of land-level changes on intertidal invertebrates,

25 with discussion of postearthquake ecological succession. In: National

26 Research Council, The Great Alaska Earthquake of 1964, Biology.

27 National Academy of Science, Washington, pp. 82-126.

28 Hawkins, S.J., Gibbs, P.E., Pope, N.D., Burt, G.R., Chesman, B.S., Bray, S.,

29 Proud, S.V., Spence, S.K., Southward, A.J., Langston, W.J., 2002.

30 Recovery of polluted ecosystems: the case for long-term studies. Marine

31 Environmental Research 54, 215-222. 
1 Hewitt, J.E., Anderson, M.J., Thrush, S.J., 2005. Assessing and monitoring ecological 2 community health in marine systems. Ecological Applications 15, 942-953.

3 Hoberg, M.K., Feder, H.M., 2002. The macrobenthos of sites within Prince William Sound, 4 Alaska, prior to the Exxon Valdez oil spill. International Review of Hydrobiology, 87, $5 \quad 25-45$.

6 Holte, B., 1998. The macrofauna and main functional interactions in the sill basin sediments 7 of the pristine Holandsfjord, northern Norway, with autecological reviews for some key8 species. Sarsia 83, 55-68.

9 Holte, B., Dahle, S., Gulliksen, B., Naes, K., 1996. Some macrofaunal effects of local

10 pollution and glacier-induced sedimentation with indicative chemical analyses, in the 11 sediments of two arctic fjords. Polar Biology 16, 549-557.

12 Holte, B., Gulliksen, B., 1998. Common macrofaunal dominant species in the sediments 13 of some north Norwegian and Svalbard glacial fjords. Polar Biology 19, 375-382.

14 Hood, D.W., Shiels, W.E., Kelley, E.J. (Eds.), 1973, Environmental studies of Port

15 Valdez. Institute of Marine Science, University of Alaska, Fairbanks, 495 pp.

16 Hubbard, J.D., 1971. Distribution and abundance of intertidal invertebrates at Olsen Bay

17 in Prince William Sound, Alaska, one year after the 1964 earthquake. In: National

18 Research Council, The Great Alaska Earthquake of 1964, Biology. National Academy

19 of Science, Washington, pp. 137-157.

20 Jewett, S.C., Dean, T.A., Laur, D.R, 1996. Effects of the Exxon Valdez oil spill on

21 benthic invertebrates in an oxygen-deficient embayment in Prince William Sound,

22 Alaska. American Fisheries Society Symposium 18, 440-447.

23 Josefson, A.B., Rosenberg, R., 1988. Long-term soft-bottom faunal changes in three

24 shallow fjords, west Sweden. Netherland Journal of Sea Research 22, 149-159.

25 Kline, T.C., Goering, J.J., Mathisen, O.A., Poe, P.H., Parker, P.L., 1990. Recycling of

26 elements transported upstream by runs of Pacific Salmon: I. ${ }^{15} \mathrm{~N}$ and ${ }^{13} \mathrm{C}$ evidence in

27 Sashin Creek, Southeastern Alaska. Canadian Journal of Fisheries and Aquatic 28 Science 47, 136-144.

29 Kline, T.C., Goering, J.J., Mathisen, O.A., Poe, P.H., Parker, P.L., Scalan, R.S., 1993.

30 Recycling of elements transported upstream by runs of Pacific Salmon: II. ${ }^{15} \mathrm{~N}$ and 
$1 \quad{ }^{13} \mathrm{C}$ evidence in Kvichak River watershed, Bristol Bay, Southwestern Alaska.

2 Canadian Journal of Fisheries and Aquatic Science 50, 2350-2365.

3 Lay, T., Kanamori, H., Ammon, C.J., Nettles, M., Ward, S.N., Aster, R.C., Beck, S.L.,

4 Bilek, S.L., Brudzinski, M.R., Butler, R., DeShon, H.R., Ekstrom, G., Satake, K.,

5 Sipkin, S., 2005. The great Sumatra-Andaman earthquake of 26 December 2004.

$6 \quad$ Science 308, 1127-1133.

7 Leung, K.M.Y., Bjørgesæter, A., Gray, J.S., Li., W.K., Lui, G.C.S., Wang, Y., Lam,

$8 \quad$ P.K.S., 2005. Deriving sediment quality guidelines from field-based species

9 sensitivity distributions. Environmental Science and Technology 39, 5148-5156.

10 Lindgarth, M., Hoskin, M., 2001. Patterns of distribution of macro-fauna in different types

11 of estuarine, soft-sediment habitats adjacent to urban and non-urban areas. Estuarine,

12 Coastal and Shelf Science 52, 237-247.

13 May, S.J., Pearson, T.H., 1995. Effects of oil-industry operations on the macrobenthos of

14 Sullom Voe. Proceedings of the Royal Society of Edinburgh (B) 103, 69-97.

15 McRoy, C.P., 1988. Natural and anthropogenic disturbances at the ecosystem level. In:

16 Shaw, D.G., Hameedi, M.J. (Eds.), Environmental studies in Port Valdez, Alaska. A

17 basis for management. Springer-Verlag, New York, pp. 329-344.

18 Molinet, C., Valle-Levinson, A., Moreno, C.A., Cáceres, M., Bello, M., Castillo, M.,

19 2006. Effects of sill processes on the distribution of epineustonic competent larvae in

20 a stratified system of Southern Chile. Marine Ecology Progress Series 324, 95-104.

21 Muench, R.D., Nebert, D.L., 1973. Physical oceanography. In: Hood, D.W., Shiels, W.E.,

22 Kelley, E.J.(Eds.), Environmental studies of Port Valdez. Institute of Marine Science,

23 University of Alaska, Fairbanks, pp. 101-150.

24 Mundy, P.R., Cooney, R.T., 2005. Physical and Biological Background. In: Mundy, P.R.

25 (Ed.), The Gulf of Alaska: Biology and Oceanography. Alaska Sea Grant College

26 Program, University of Alaska Fairbanks, pp. 15-24.

27 Mundy, P.R., Spies, R., 2005. Introduction. In: Mundy, P.R. (Ed.), The Gulf of Alaska:

28 Biology and Oceanography. Alaska Sea Grant College Program, University of Alaska

29 Fairbanks, pp. 1-14.

30 Muslow, S., Krieger, Y., Kennedy, R., 2006. Sediment profile imaging (SPI) and micro-

31 electrode technologies in impact assessment studies: example from two fjords in 
1 Southern Chile used for fish farming. Journal of Marine Systems 62, 152-163.

2 Naidu, A.S., Klein, L.H., 1988. Sedimentation processes. In: Shaw, D.G., Hameedi, M.J.

3 (Eds.), Environmental studies in Port Valdez, Alaska. A basis for management.

4 Springer-Verlag, New York, pp. 69-91.

5 Naiman, R.J., Bilby, R.E., Schindler, D.E., Helfield, J.M., 2002. Pacific Salmon,

6 nutrients, and the dynamics of freshwater and riparian ecosystems. Ecosystems 5,

$7 \quad 399-417$.

8 Neal, E.G., Walter, M.T., Coffeen, C., 2002. Linking the pacific decadal osscilation to

9 seasonal stream discharge patterns in Southeast Alaska. Journal of Hydrology 263,

$10 \quad 188-197$.

11 Nichols, F.H., 1985. Abundance fluctuations among benthic invertebrates in two pacific 12 estuaries. Estuaries 8, 136-144.

13 Nichols, F.H., Thompson, J.K., 1985. Persistence of an introduced mudflat community in

14 South San Francisco Bay, California. Marine Ecology Progress Series 24, 83-97.

15 NRC, 1971. National Research Council, The Great Alaska Earthquake of 1964, Biology.

16 National Academy of Science, Washington, 285 pp.

17 Oug, E., 2000. Soft-bottom macrofauna in the high-latitude ecosystem of Balsford,

18 northern Norway: Species composition, community structure, and temporal

19 variability. Sarsia 85, 1-13.

20 Pearson, T.H., Barnett, P.R.O., 1987. Long-term changes in benthic populations in some

21 west European coastal areas. Estuaries 3, 220-226.

22 Pearson, T.H., Barnett, P.R.O., Nuttall, J., 1986. Long term changes in the benthic

23 communities of Loch Linnhe and Loch Eil (Scotland). Hydrobiologia, 142, 113-119.

24 Perus, J., Bonsdorff, E., 2004. Long-term changes in macrozoobenthos in the Åland

25 archipelago, northern Baltic Sea. Journal of Sea Research 52, 455-56.

26 Pinchuk, A.I., Coyle, K.O., Hopcroft, R.R., 2008. Climate-related variability in

27 abundance and reproduction of euphausiids in the northern Gulf of Alaska in 1998-

28 2003. Progress in Oceanography 77, 203-216.

29 Ray, G.C., 2005. Connectivities of estuarine fishes to the coastal realm. Estuarine,

$30 \quad$ Coastal and Shelf Science 64, 18-32. 
1 Reise, K., 2002. Sediment mediated species interactions in coastal waters. Journal of Sea $2 \quad$ Research 48, 127-141.

3 Renaud, P.E., Wlodarska-Kowalczuk, M., Trannum, H., Holte, B., Węsławski, J.M.,

4 Cochrane, S., Dahle, S., Gulliksen, B., 2007. Multidecadal stability of benthic

5 community structure in a high-Arctic glacial fjord (van Mijenfjord, Spitsbergen).

6 Polar Biology 30, 295-305.

7 Ribeiro Jr., P.J., Diggle, P.J., 2001. geoR: A package for geostatistical analysis. R-NEWS

8 1(2), 15-18. ISSN 1609-3631. http://cran.r-project.org/doc/Rnews.

9 Richardson, J., Erickson, G., 2005. Economics of human uses and activities in the

10 Northern Gulf of Alaska. In: Mundy, P.R. (Ed.), The Gulf of Alaska: Biology and

11 Oceanography. Alaska Sea Grant College Program, University of Alaska Fairbanks,

12 pp. 117-138.

13 Ríos, C., Mutschke, E., Montiel, A., Gerdes, D., Arntz, W. E., 2005. Soft-bottom

14 macrobenthic faunal associations in the southern Chilean glacial fjord complex.

15 Scientia Marina 69, 225-236.

16 Royer, T.C., Grosch, C.E., Mysak, L.A., 2001. Interdecadal variability of Northeast

17 Pacific coastal freshwater and its implications on biological productivity. Progress in

18 Oceanography 49, 95-111.

19 Sargent, J.R., Hopkins, C.C.E., Seiring, J.V., Youngson, A., 1983. Partial

20 characterization of organic material in surface sediments from Balsfjorden, northern

21 Norway, in relation to its origin and nutritional value for sediment-ingesting animals.

22 Marine Biology 76, 87-94.

23 Schiff, K.C., Allen, M.J., Zeng, E.Y., Bay, S.M., 2000. Southern California. Marine 24 Pollution Bulletin 41, 76-93.

25 Sharma, G.D., Burbank, D.C., 1973. Geological oceanography. In: Hood, D.W., Shiels, 26 W.E., Kelley, E.J. (Eds.), Environmental studies of Port Valdez. Institute of Marine 27 Science, University of Alaska, Fairbanks, pp. 15-100.

28 Shaw, D.G., 1988. Hydrocarbon accumulations. In: Shaw, D.G., Hameedi, M.J. (Eds.),

29 Environmental studies in Port Valdez, Alaska. A basis for management. Springer-

30 Verlag, New York, pp. 267-292.

31 Shaw, D.G., Hameedi, M.J. (Eds.), 1988. Environmental studies in Port Valdez, Alaska: 
1 A basis for management. New York: Springer-Verlag, $423 \mathrm{pp}$.

2 Snelgrove, P.V.R, Butman, C.A., 1994. Animal-sediment relationships revisited: cause

3 versus effect. Oceanography and Marine Biology: an Annual Review 32, 111-177.

4 Stanley, K.W., 1968. Effects of the Alaska earthquake of March 27, 1964 on shore

5 processes and beach morphology. Geological Survey Professional Papers 543-J. U.S.

6 Government Printing Office, Washington, D.C., 21 pp.

7 Stein, A., van Groenigen, J.W., Jeger, M.J., Hoosbeek, M.R., 1998. Space-time statistics

8 for environmental and agricultural related phenomena. Environmental and Ecological

9 Statistics 5, 155-172.

10 Steneck, R.S., Carlton, J.T., 2001. Human alterations of marine communities: students

11 beware! In: Bertness, M.D., Gaines, S.D., Hay, M.E. (Eds.), Marine community

12 ecology. Sinauer Associates, Sunderland MA, USA, pp. 445-468.

13 Wake, H., 2002. Oil refineries: a review of their ecological impacts on the aquatic

14 environment. Estuarine, Coastal and Shelf Science 62, 131-140.

15 Warwick, R.M., Clarke, K.R., 1993. Increased variability as a symptom of stress in

16 marine communities. Journal of Experimental Marine Biology and Ecology 172, 215-

17226.

18 Weingartner, T.J., Danielson, S.L., Royer, T.C., 2005. Freshwater variability and

19 predictability in the Alaska Coastal Current. Deep-Sea Research II 52, 169-191.

20 White, B., 2008. Alaska salmon enhancement program 2007 annual report. Alaska

21 Department of Fish and Game, Fisheries management report No. 08-03, Anchorage,

22 Alaska, unpublished.

23 Wiegers, J.K., Feder, H.M., Mortensen, L.S., Shaw, D.G, Wilson, V.J., Landis, W.G.,

24 1998. A regional multiple-stressor rank-based ecological risk assessment for the fjord

25 of Port Valdez, Alaska. Human and Ecological Risk Assessment 4, 1125-1173.

26 Whomersley, P., Schratzberger, M., Huxham, M., Bates, H., Rees, H., 2007. The use of

27 time-series data in the assessment of macrobenthic community change after the

28 cessation of sewage-sludge disposal in Liverpool Bay (UK). Marine Pollution

29 Bulletin 54, 32-41. 
1 Wlodarska-Kowalczuk, M., Kedra, M., 2007. Surrogacy in natural patterns of benthic

2 distribution and diversity: selected taxa versus lower taxonomic resolution, Marine

3 Ecology Progress Series 351, 53-63.

4 Wlodarska-Kowalczuk, M., Pearson, T.H., 2004. Soft-bottom macrobenthic faunal

5 associations and factors affecting species distributions in an arctic glacial fjord

6 (Kongsfjord, Spitsbergen). Polar Biology 27, 155-167.

7 Wlodarska-Kowalczuk, M., Pearson, T.H., Kendal, M.A., 2005. Benthic response to

8 chronic natural disturbance by glacial sedimentation in an Arctic fjord. Marine

$9 \quad$ Ecology Progress Series 303, 31-41.

10 Wlodarska-Kowalczuk, M., Węslawski, J.M., Kotwicki, L., 1998. Spitsbergen glacial

11 bays macrobenthos - a comparative study. Polar Biology 20, 66-73.

12 
Table 1. Summary measures from Port Valdez, Alaska 1971-2007. \#Stat $=$ number of stations per transect, abund. = abundance, $\mathrm{PDO}=$ average annual pacific decadal oscillation index, temp $=$ annual temperature $(\mathrm{C})$, snowfall = total annual snowfall $(\mathrm{m})$, precip $=$ total annual precipitation $(\mathrm{m})$, and N/A $=$ not available. Units for the variables are ind. $\mathrm{m}^{-2}$ for abundance, $\mathrm{g} \mathrm{m}^{-2}$ for biomass, $\mathrm{ng} \mathrm{g}^{-1}$ for $\mathrm{PAH}$, and millions $\mathrm{yr}^{-1}$ for salmon releases and returns.

\begin{tabular}{|c|c|c|c|c|c|c|c|c|c|c|c|c|c|c|}
\hline Year & \#Stat & Abun. & SD & Biomass & SD & Total Taxa & PAH & SD & Salmon Rels. & Salmon Ret. & $\mathrm{PDO}$ & Temp & Snowfall & Precip \\
\hline 1971 & 5 & 207 & 54 & 15.99 & 7.79 & 29 & $\mathrm{~N} / \mathrm{A}$ & $\mathrm{N} / \mathrm{A}$ & $\mathrm{N} / \mathrm{A}$ & N/A & -1.29 & $\mathrm{~N} / \mathrm{A}$ & $\mathrm{N} / \mathrm{A}$ & $\mathrm{N} / \mathrm{A}$ \\
\hline 1976 & 5 & 494 & 245 & 16.79 & 4.56 & 51 & 6.9 & 12.15 & $\mathrm{~N} / \mathrm{A}$ & N/A & 0.01 & 3.39 & 1.98 & 8.92 \\
\hline 1977 & 5 & 327 & 171 & 21.24 & 15.50 & 30 & 2.8 & 0.36 & N/A & N/A & 0.23 & 3.78 & 1.59 & 9.63 \\
\hline 1980 & 5 & 156 & 29 & 31.33 & 22.61 & 35 & 5.8 & 3.26 & N/A & N/A & 0.60 & 3.44 & 1.76 & 7.66 \\
\hline 1981 & 6 & 215 & 74 & 11.83 & 6.98 & 48 & 6.4 & 4.51 & $\mathrm{~N} / \mathrm{A}$ & $\mathrm{N} / \mathrm{A}$ & 0.92 & 4.28 & 2.37 & 6.11 \\
\hline 1982 & 6 & 353 & 174 & 14.66 & 10.31 & 46 & 2.3 & 3.62 & 8 & $\mathrm{~N} / \mathrm{A}$ & 0.11 & 2.67 & 1.56 & 6.54 \\
\hline 1985 & 6 & 212 & 50 & 7.02 & 8.85 & 37 & 5.9 & 1.15 & 54 & 0.6 & 0.45 & 2.72 & 1.94 & 8.61 \\
\hline 1987 & 3 & 589 & 287 & 7.28 & 1.08 & 41 & $\mathrm{~N} / \mathrm{A}$ & N/A & 63 & 5.6 & 1.82 & 4.39 & 1.95 & 9.77 \\
\hline 1989 & 5 & 231 & 72 & 9.61 & 6.76 & 43 & 120.2 & 76.7 & 132 & 3.5 & -0.18 & 3.50 & 2.19 & 7.95 \\
\hline 1990 & 6 & 274 & 71 & 20.07 & 27.52 & 50 & 235.6 & 127.7 & 126 & 11.1 & -0.36 & 3.17 & 1.71 & 13.99 \\
\hline 1991 & 6 & 355 & 31 & 22.51 & 28.33 & 50 & 66.1 & 37.2 & 134 & 6.1 & -0.42 & 4.11 & 1.72 & 8.31 \\
\hline 1992 & 5 & 476 & 149 & 21.05 & 18.25 & 43 & 56.8 & 29.3 & 91 & 2.2 & 0.93 & 3.56 & 2.16 & 13.10 \\
\hline 1993 & 5 & 450 & 53 & 18.27 & 11.48 & 49 & 30.0 & 13.1 & 160 & 1.8 & 1.42 & 4.83 & 2.16 & 8.72 \\
\hline 1994 & 5 & 354 & 37 & 18.51 & 12.64 & 45 & 39.8 & 18.5 & 156 & 13.3 & -0.15 & 3.61 & 1.76 & 8.68 \\
\hline 1995 & 5 & 387 & 87 & 24.50 & 22.87 & 48 & 39.8 & 18.5 & 208 & 6.8 & 0.64 & 4.06 & 1.41 & 10.08 \\
\hline 1996 & 5 & 404 & 42 & 15.89 & 11.21 & 49 & 29.0 & 11.7 & 225 & 7.8 & 0.64 & 3.39 & 1.29 & 6.79 \\
\hline 1997 & 5 & 459 & 143 & 14.36 & 4.19 & 52 & 24.7 & 13.4 & 190 & 7.1 & 1.46 & 4.89 & 1.73 & 5.86 \\
\hline 1998 & 5 & 337 & 76 & 13.28 & 6.27 & 41 & 25.2 & 12.4 & 197 & 4.7 & 0.25 & 4.22 & 1.46 & 7.05 \\
\hline 1999 & 5 & 313 & 41 & 20.03 & 9.62 & 44 & 22.1 & 7.1 & 216 & 14.6 & -1.06 & 3.33 & 1.84 & 8.66 \\
\hline 2000 & 5 & 260 & 47 & 26.16 & 13.59 & 44 & 22.9 & 7.2 & 197 & 12.4 & -0.59 & 4.33 & 1.58 & 9.58 \\
\hline 2001 & 5 & 429 & 105 & 20.58 & 14.42 & 48 & 25.9 & 9.5 & 204 & 16.0 & -0.56 & 3.83 & 1.77 & 9.94 \\
\hline 2002 & 6 & 365 & 69 & 21.81 & 20.07 & 47 & 22.3 & 7.7 & 204 & 5.2 & 0.22 & 4.61 & 2.14 & 8.56 \\
\hline 2003 & 3 & 534 & 286 & 13.62 & 8.79 & 36 & 38.2 & 28.7 & 208 & 16.4 & 0.97 & 4.72 & 1.65 & 6.36 \\
\hline 2004 & 3 & 381 & 139 & 14.04 & 8.85 & 37 & 38.5 & 26.7 & 224 & 11.3 & 0.35 & 4.56 & 1.77 & 8.98 \\
\hline 2005 & 3 & 334 & 85 & 33.79 & 20.22 & 32 & 41.5 & 26.5 & 224 & 18.4 & 0.38 & 4.67 & 1.90 & 7.82 \\
\hline 2006 & 3 & 529 & 146 & 18.95 & 12.45 & 31 & 50.3 & 28.0 & 218 & 12.3 & 0.19 & 3.11 & 1.81 & 6.03 \\
\hline 2007 & 3 & 481 & 143 & 24.40 & 17.92 & 35 & 31.7 & 14.8 & 222 & 14.3 & -0.20 & 3.50 & 1.20 & 6.99 \\
\hline
\end{tabular}


Table 2. Spearman correlations $(\rho)$ of benthic indices, measures of anthropogenic stress, and climatic variables, from Port Valdez, Alaska 1982-2007. Values in bold are significant at $\alpha=0.10$.

\begin{tabular}{lccccccc} 
Variables & PAH & Releases & Returns & PDO & Temperature & Snowfall & Precipitation \\
\hline Abundance & 0.29 & 0.23 & 0.12 & $\mathbf{0 . 3 8}$ & 0.25 & -0.02 & -0.05 \\
Biomass & 0.12 & 0.35 & $\mathbf{0 . 4 0}$ & -0.31 & 0.03 & 0.26 & -0.28 \\
\# Taxa & 0.05 & -0.27 & -0.24 & 0.06 & 0.07 & 0.13 & 0.06 \\
\hline
\end{tabular}


December 11, 2008

Figure 1. Sites sampled for benthic fauna in Port Valdez, Alaska, 1971-2007. The 1971 and 2002 grid sites are shown with the 1971-2007 transect sites identified by their station numbers. The dotted line represents the division between eastern and western stations as described by Feder and Matheke (1980).

Figure 2. Sediment flux in Port Valdez, 1976 To 1978.

Figure 3. MDS ordination of abundance data for the benthos transect sites from Port Valdez, 1971, 1976, 1981, 1985, 1990, 1995, 2000, and 2005. Data are $\ln (X+1)$ transformed average abundance of infaunal families (ind. $\mathrm{m}^{-2}$ ). Circles on the MDS plot represent year groupings. Average abundance and percent of total group abundance of dominant fauna, as suggested by SIMPER rankings, are presented for each year grouping.

Figure 4. Bubble and bar plots of the abundance (ind. $\mathrm{m}^{-2}$ ) of selected fauna from Port Valdez, 1971 and 2002. Bar plots include 95\% confidence intervals of average abundance (ind. $\mathrm{m}^{-2}$ ). The dashed lines in the plots represent the division between eastern and western stations. P-values from ANOVA are given following the comparisons for year $(\mathrm{Y})$, location $(\mathrm{L})$, and the interaction $(\mathrm{YxL})$

Figure 5. Bubble plot of the abundance (ind. $\mathrm{m}^{-2}$ ) of the polychaete Galathowenia oculata of the family Oweniidae in Port Valdez, 1971 to 2002. The thin dashed lines represent the boundaries for sampling in each year. Abundance data were ranktransformed prior to ANOVA. See legend of Figure 4 for further details.

Figure 6. Spatio-temporal model and whisker plots of abundance (ind. $\mathrm{m}^{-2}$ ) for deep stations from Port Valdez, 1971-2007. Distances are from station $50(0 \mathrm{~km})$ in the west near the mouth to station $11(14 \mathrm{~km})$ in the east near the head of the fjord. Whisker plots are mean abundance with $95 \%$ confidence intervals. The dotted lines in the whisker plots are the grand means and the solid lines are estimated curve lines to show the general trends.

Figure 7. Spatio-temporal model and whisker plots of biomass $\left(\mathrm{g} \mathrm{m}^{-2}\right)$ for deep stations from Port Valdez, 1971-2007. See legend of Figure 6 for details.

Figure 8. Spatio-temporal model and whisker plots of the number of taxa for deep stations from Port Valdez, 1971-2007. See legend of Figure 6 for details.

Figure 9. Plot of mean abundance (ind. $\mathrm{m}^{-2}$ ) for the deep-basin station transect from Port Valdez and the annual mean pacific decadal oscillation index (PDO), 1971-2007. The dashed line indicates 0 for the PDO index. PDO values above the line indicate warm years and values below the line cold years. Major events occurring in the fjord are listed and indicated on the horizontal axis of the plot by an asterisk. 


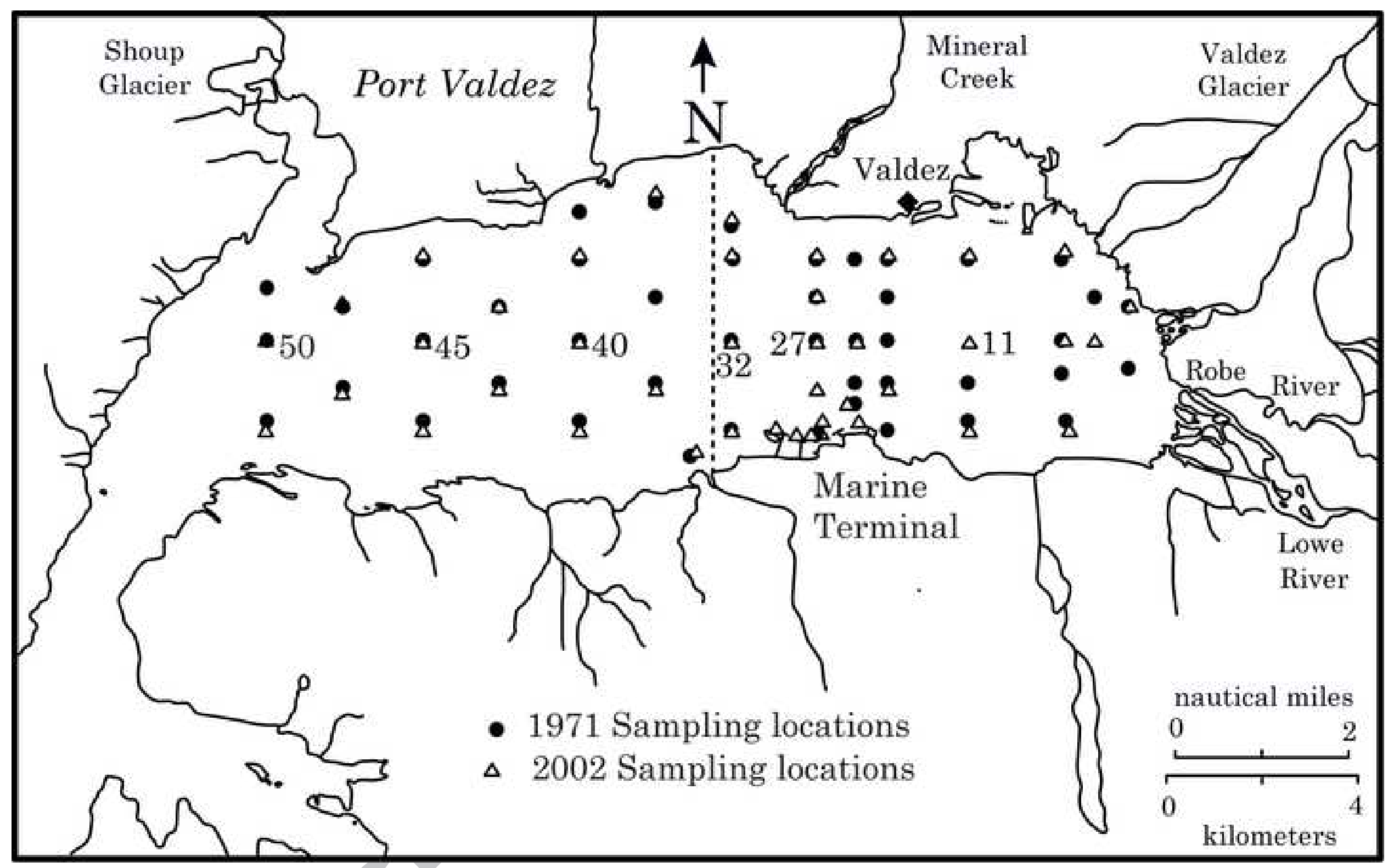




\section{ACCEPTED MANUSCRIPT}

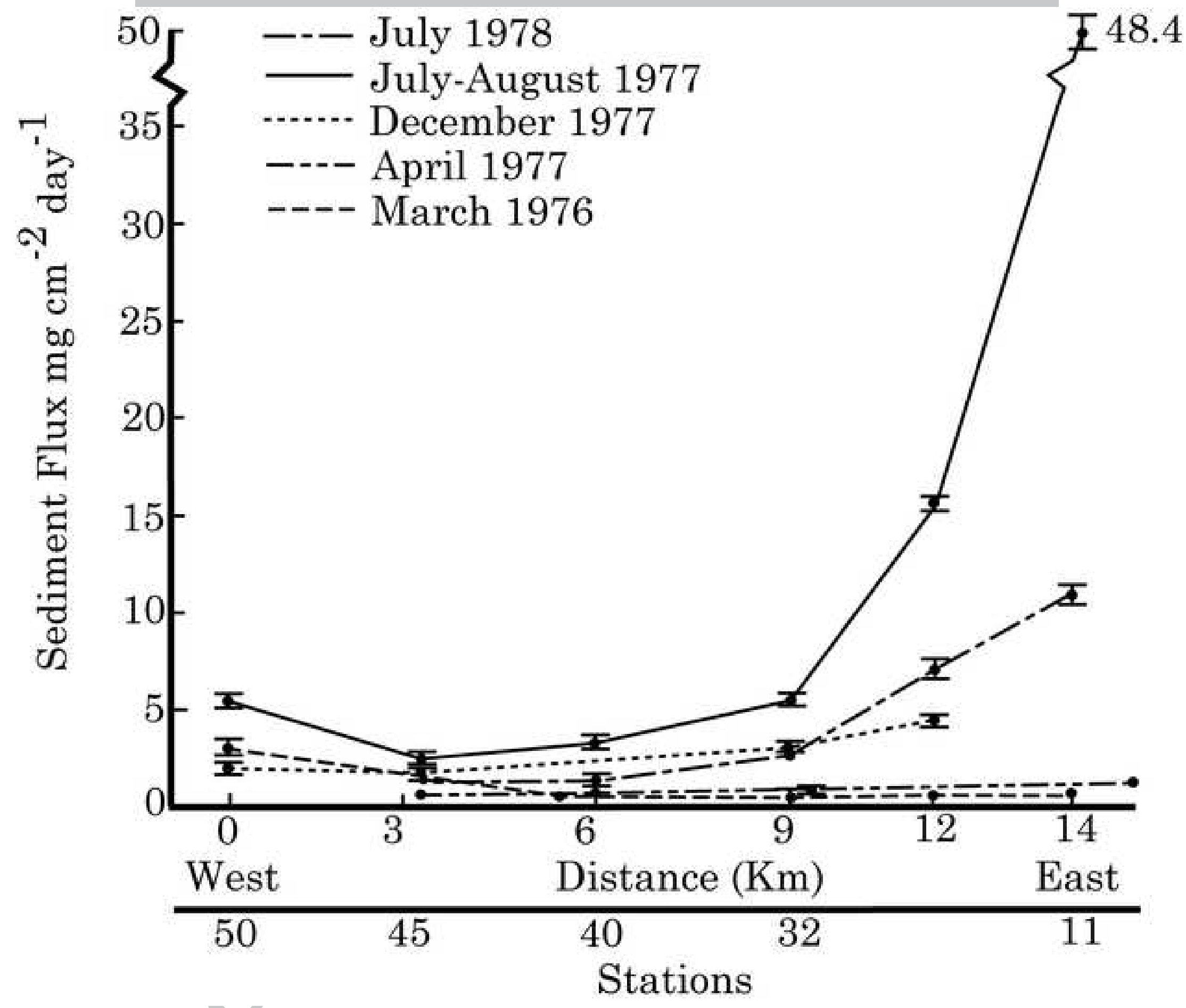




\section{ACCEPTED MANUSCRIPT}

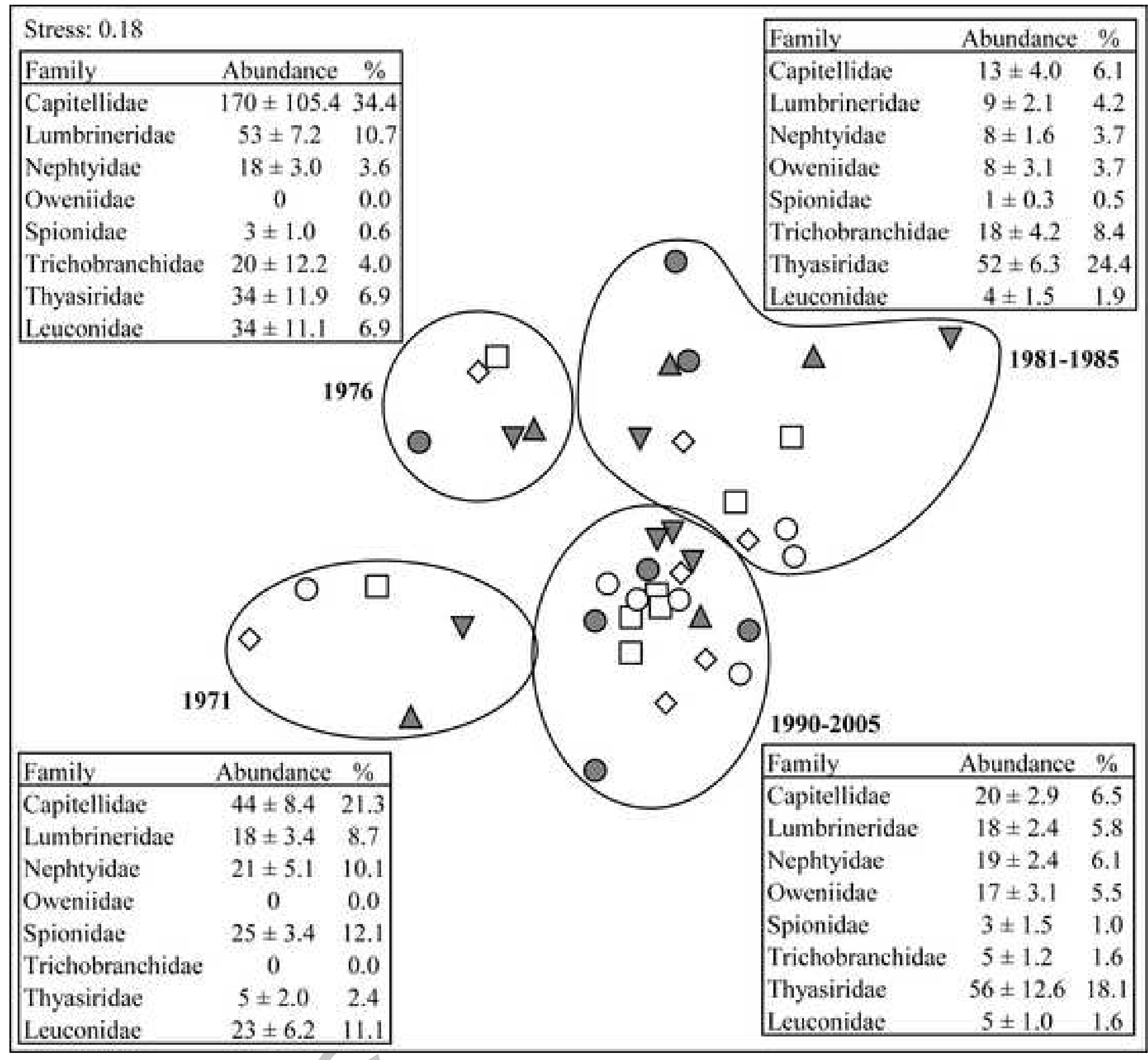

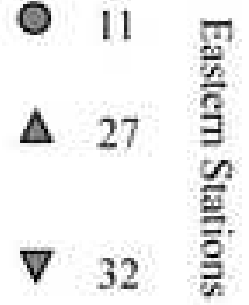

40

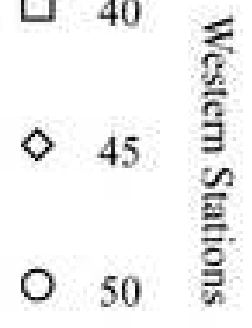$$
\text { . }
$$ 
Figure 4

\section{ACCEPTED MANUSCRIPT}
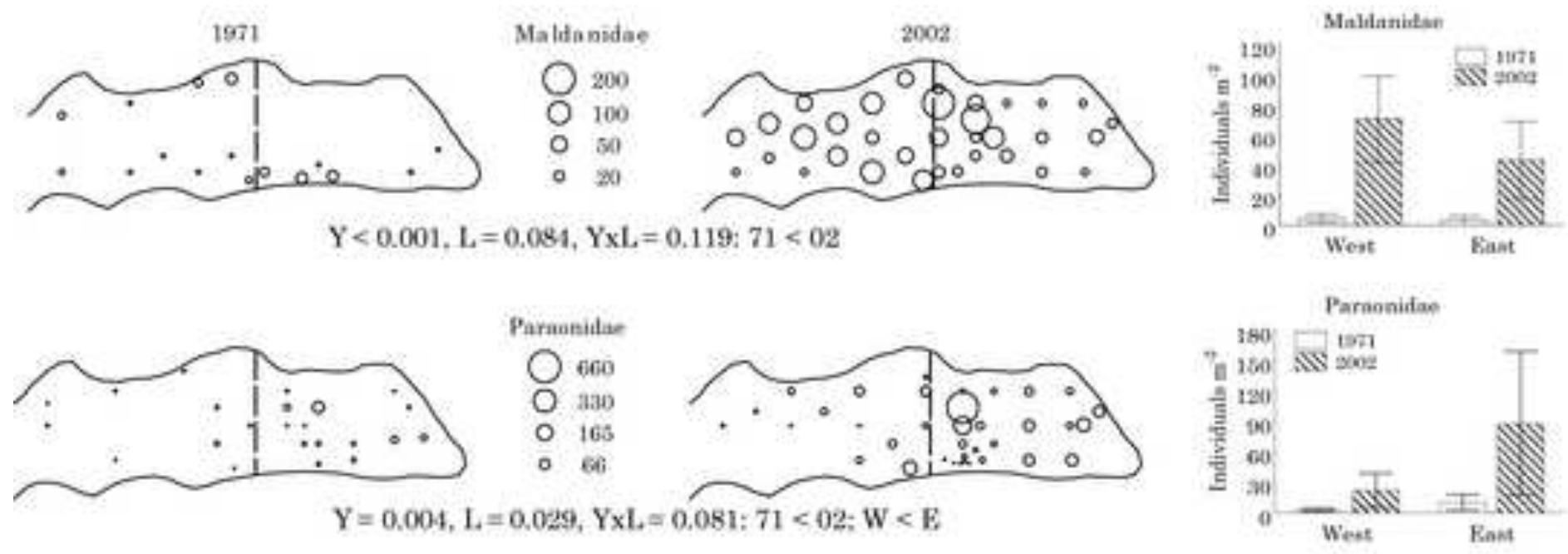

Trichehranchidas
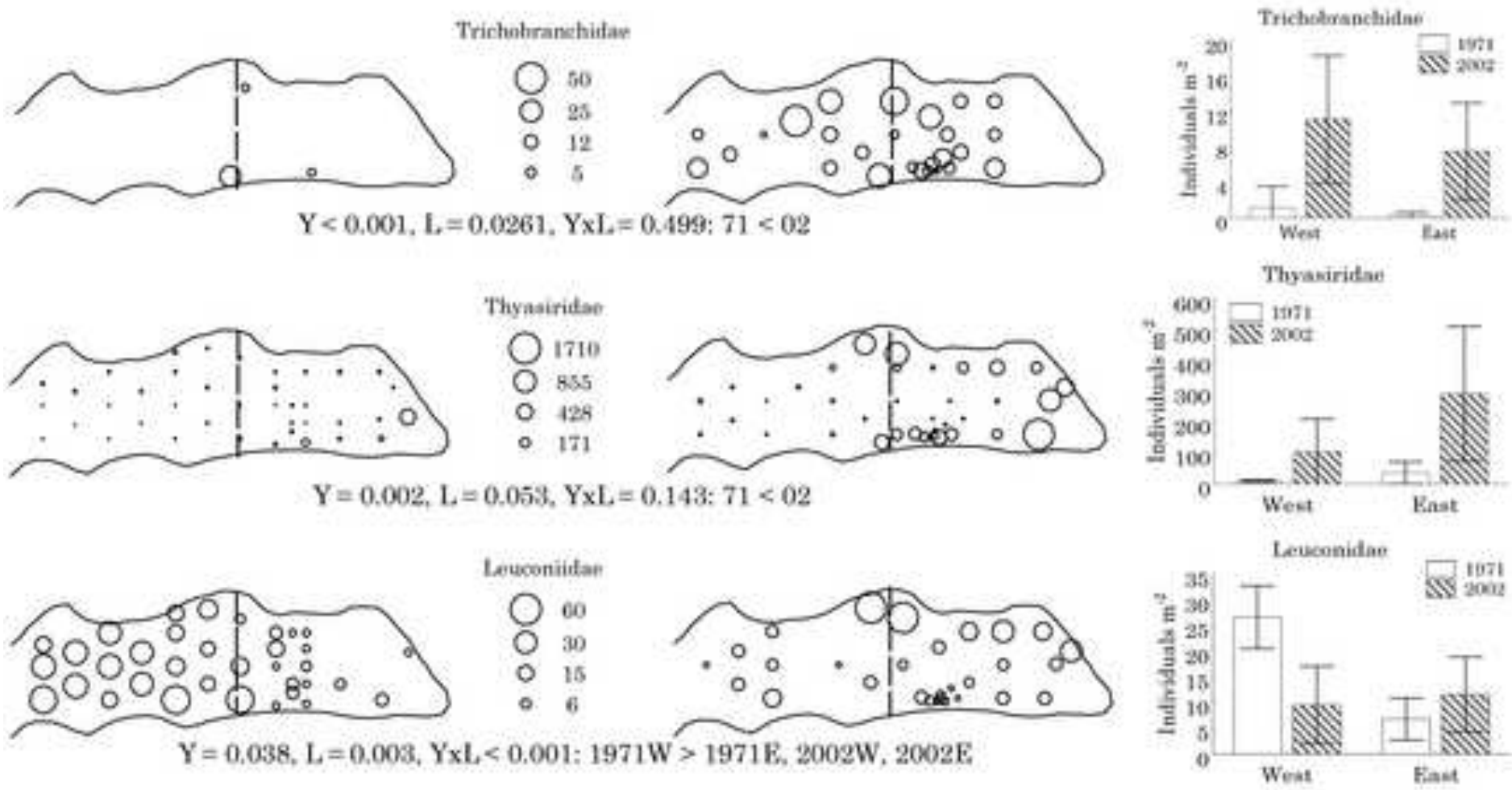

Ophiuritae (O) + Amphiuridae (D)
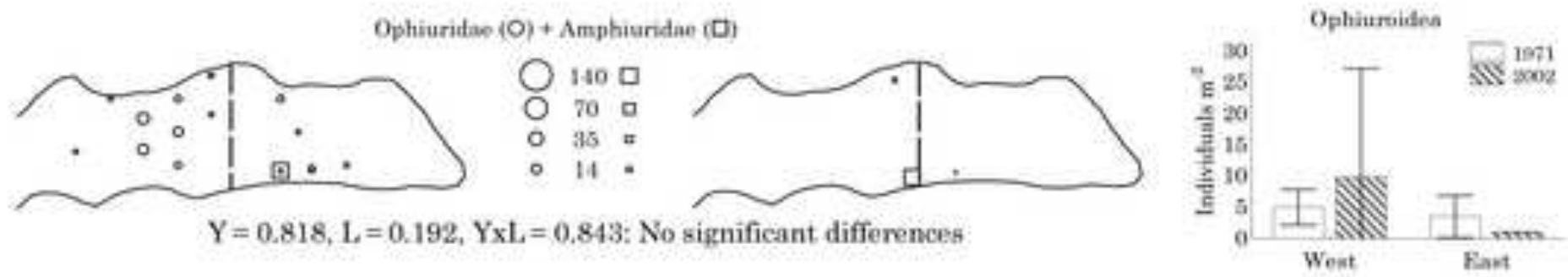


\section{ACCEPTED MANUSCRIPT}
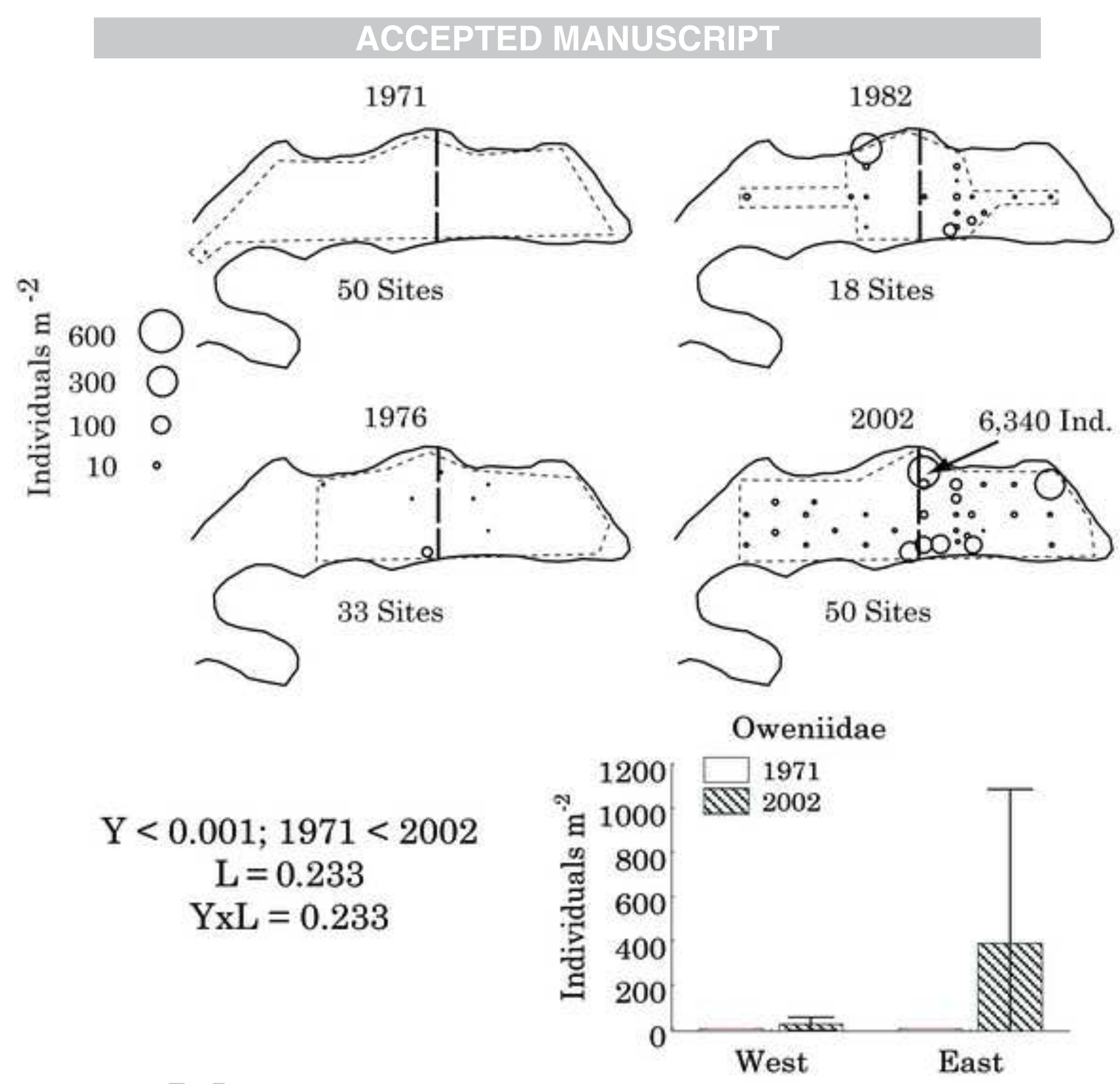


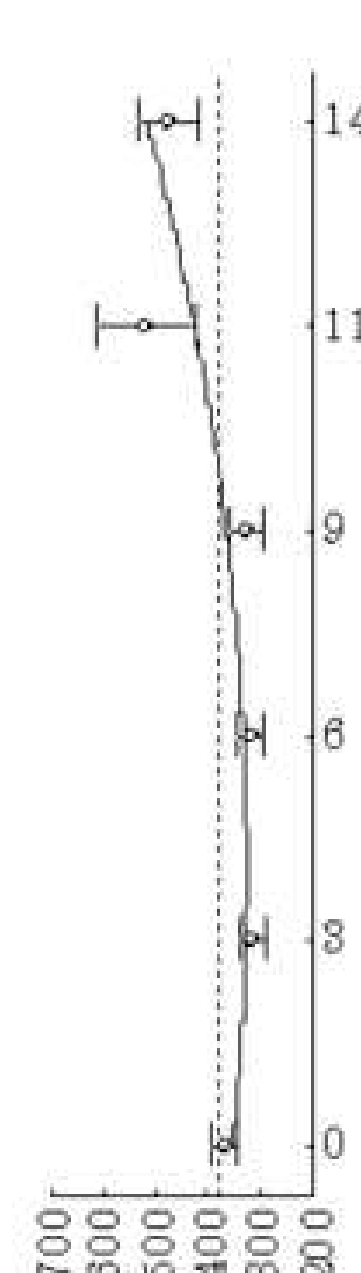

Ind. $\mathrm{m}^{-2}$
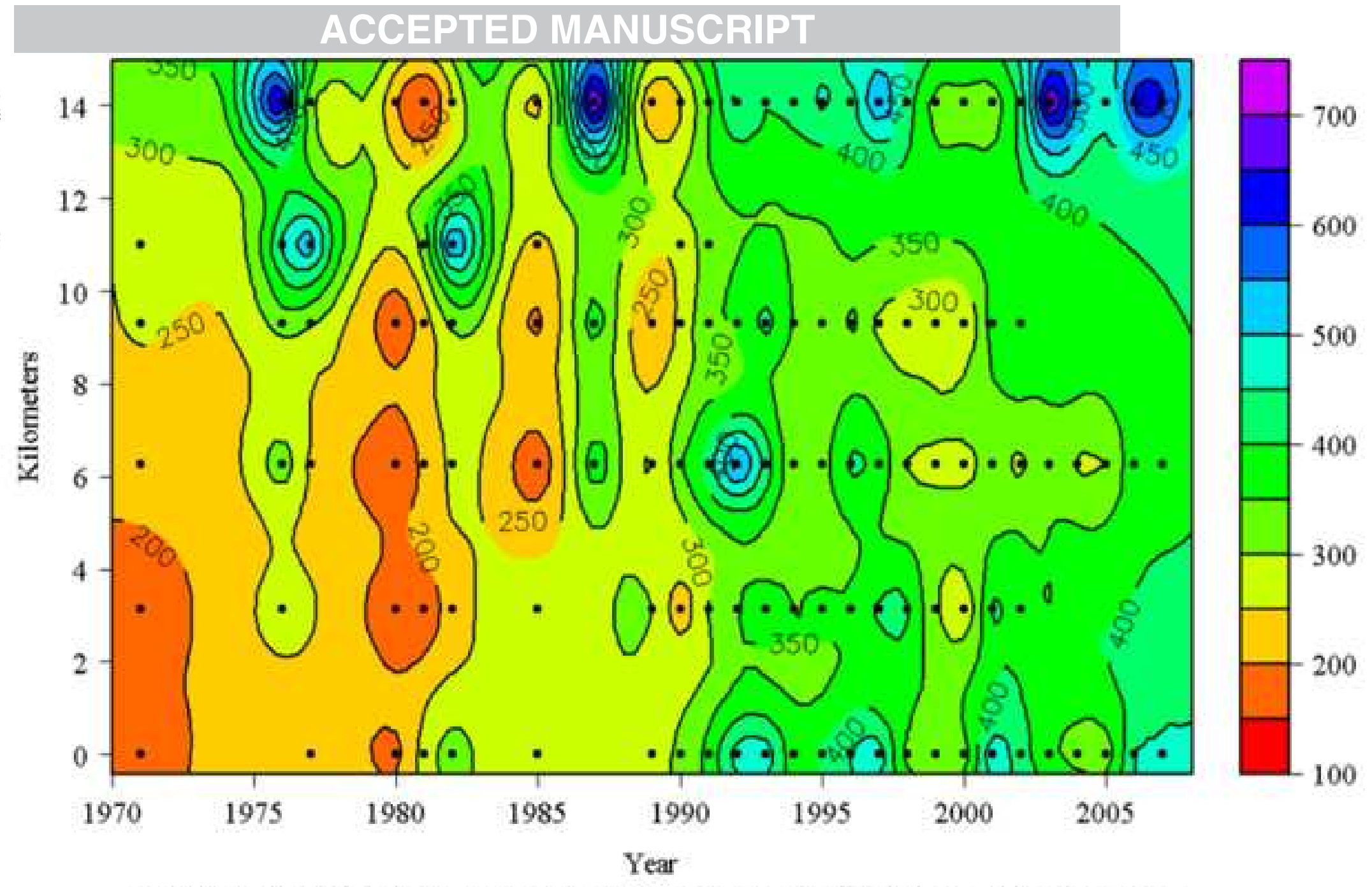

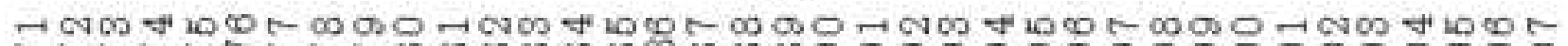

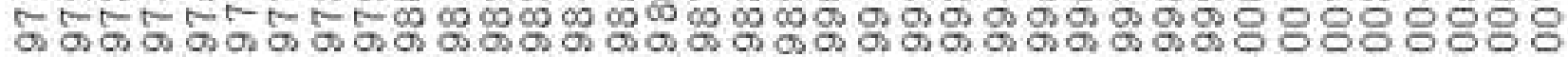

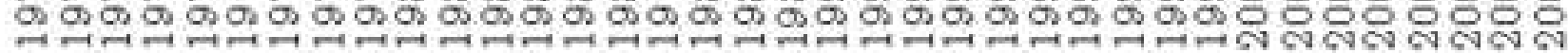

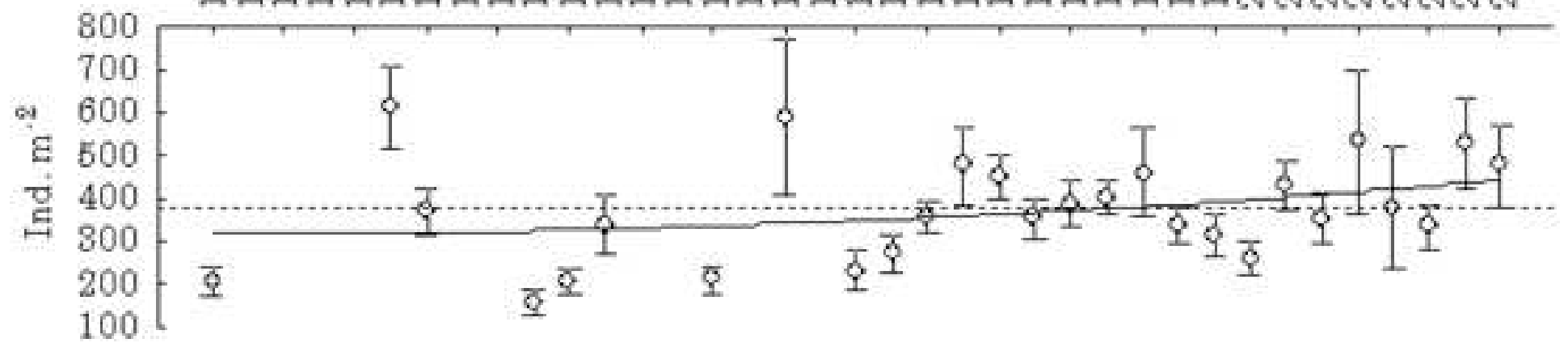




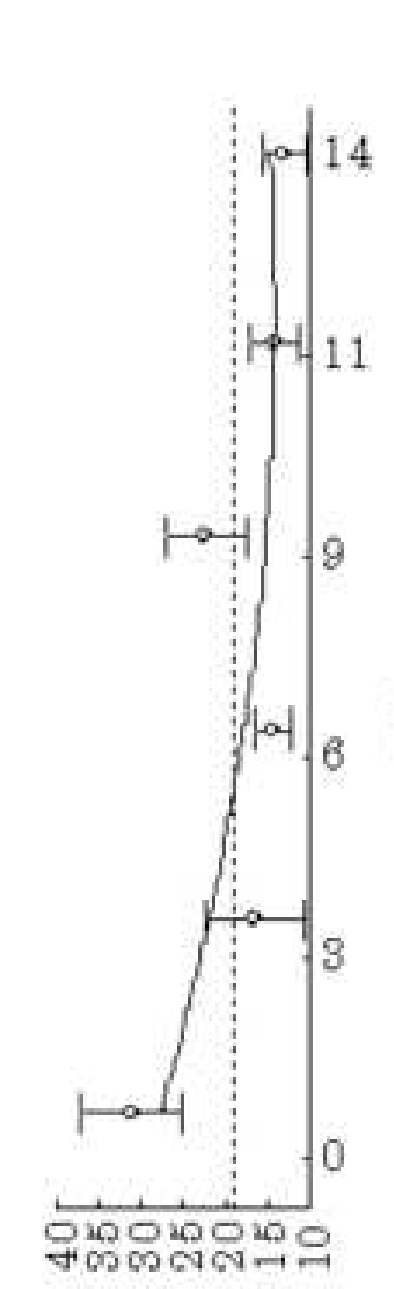

$G \mathrm{~m}^{2}$
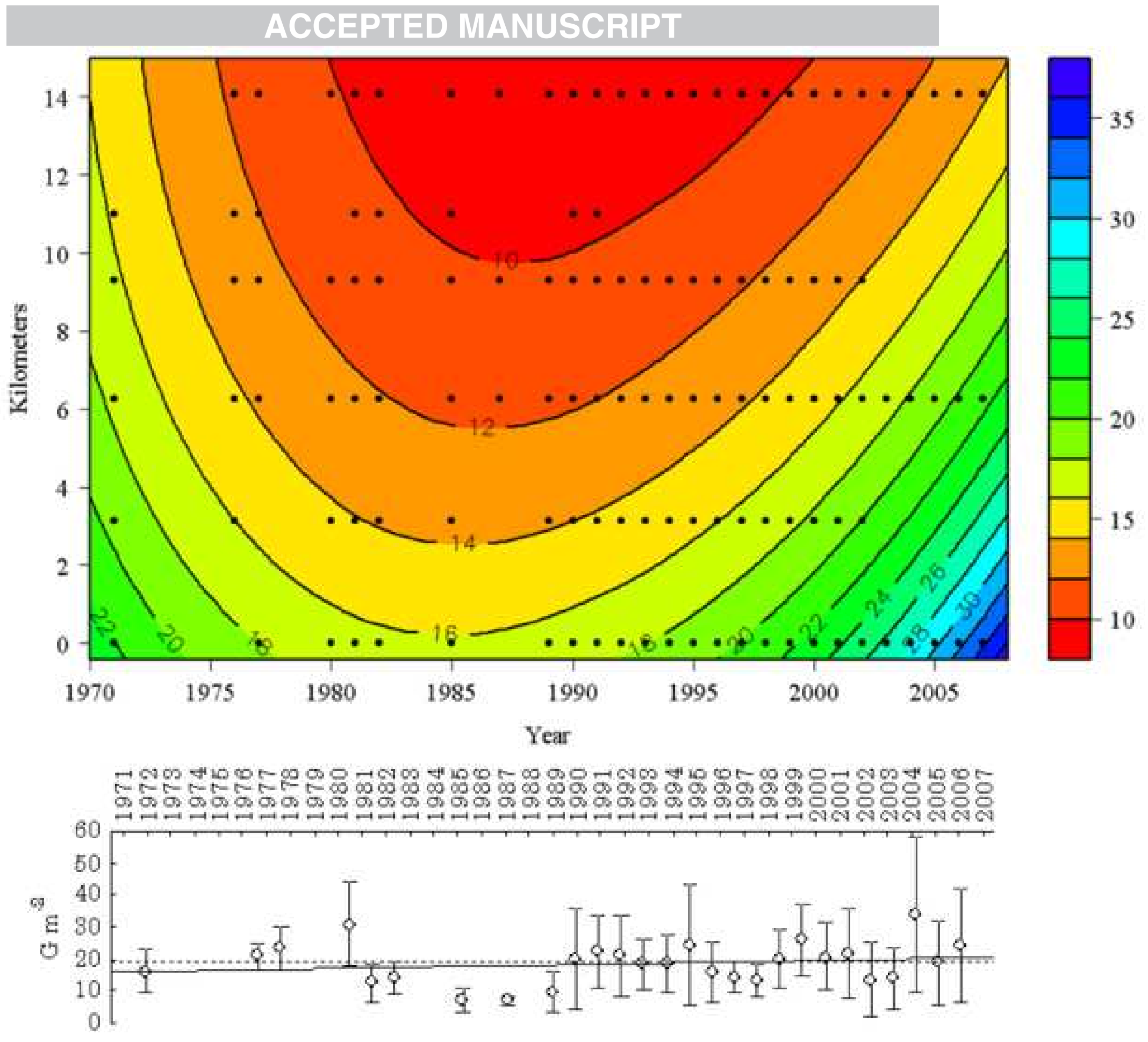


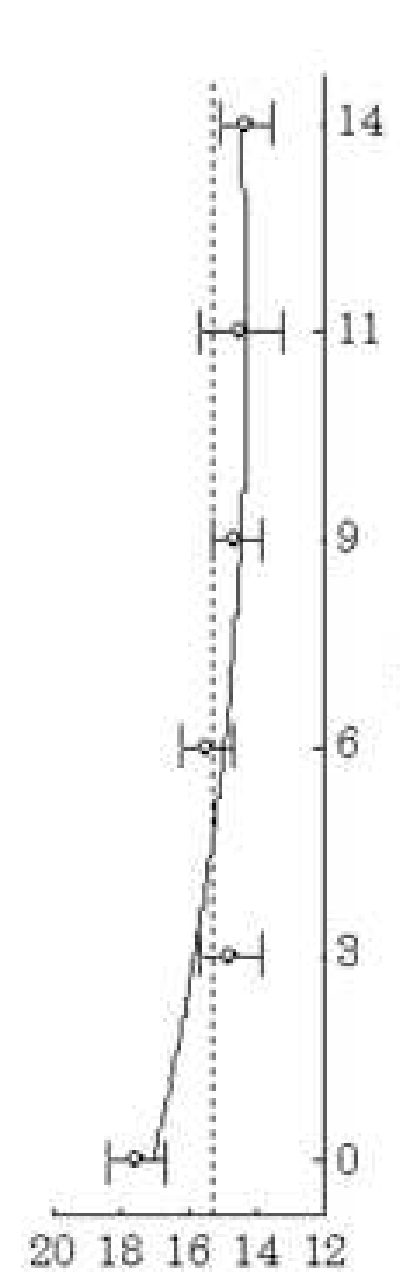

Number Taxa
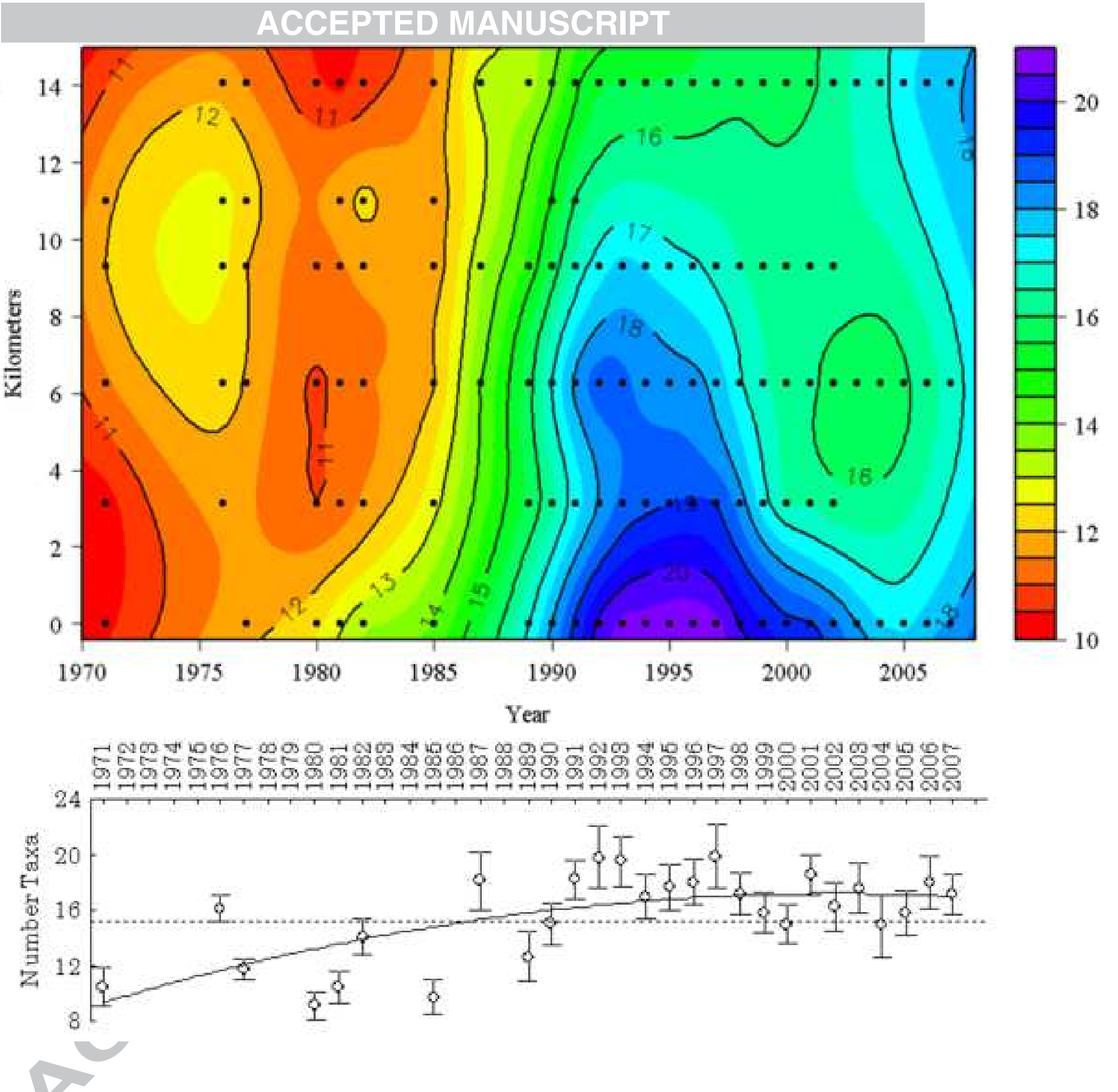


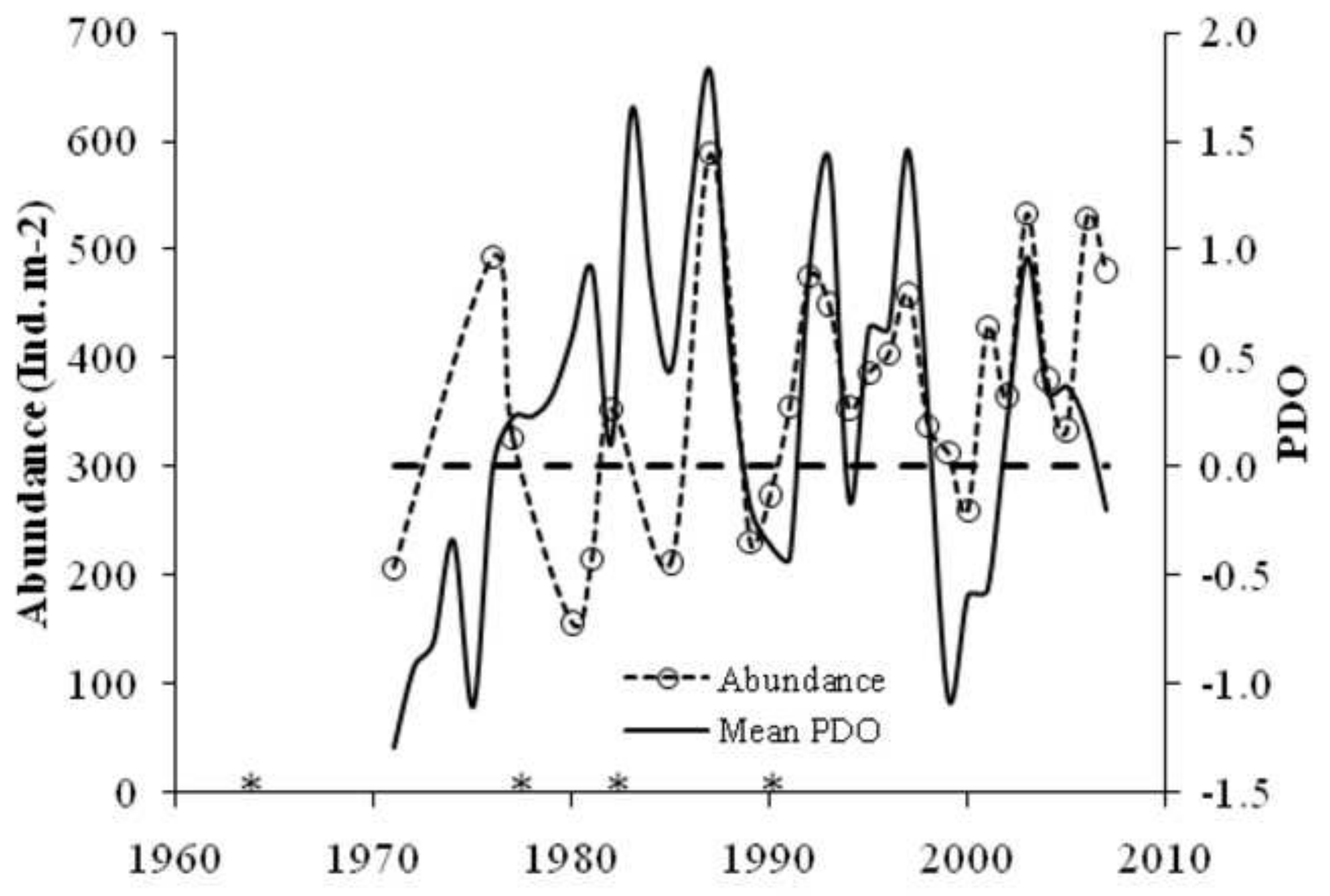

1964 - 9.2 magnitude earthquake $1990->100$ mill. hatchery salmon 1977 - Oil terminal operational 1983 - First hatchery salmon retums. 